University of Nebraska - Lincoln

DigitalCommons@University of Nebraska - Lincoln

Biological Systems Engineering: Papers and

Publications

Biological Systems Engineering

2012

\title{
Global estimation of evapotranspiration using a leaf area index- based surface energy and water balance model
}

H. Yan

China Meteorological Administration, yanhaon@yahoo.com.cn

S.Q. Wang

Chinese Academy of Sciences, sqwang@igsnrr.ac.cn

David P. Billesbach

University of Nebraska-Lincoln, dbillesbach1@unl.edu

Walter Oechel

San Diego State University, oechel@sunstroke.sdsu.edu

J.H. Zhang

Chinese Academy of Meteorological Sciences, zhangjh@cams.cma.gov.cn

See next page for additional authors

Follow this and additional works at: https://digitalcommons.unl.edu/biosysengfacpub

Part of the Biological Engineering Commons

Yan, H.; Wang, S.Q.; Billesbach, David P.; Oechel, Walter; Zhang, J.H.; Meyers, Tilden; Martin, TA.; Matamala, Roser; Baldocchi, Dennis D.; Bohrer, G.; Dragoni, D.; and Scott, R., "Global estimation of evapotranspiration using a leaf area index-based surface energy and water balance model" (2012). Biological Systems Engineering: Papers and Publications. 232.

https://digitalcommons.unl.edu/biosysengfacpub/232

This Article is brought to you for free and open access by the Biological Systems Engineering at DigitalCommons@University of Nebraska - Lincoln. It has been accepted for inclusion in Biological Systems Engineering: Papers and Publications by an authorized administrator of DigitalCommons@University of Nebraska Lincoln. 


\section{Authors}

H. Yan, S.Q. Wang, David P. Billesbach, Walter Oechel, J.H. Zhang, Tilden Meyers, TA. Martin, Roser Matamala, Dennis D. Baldocchi, G. Bohrer, D. Dragoni, and R. Scott 


\title{
Global estimation of evapotranspiration using a leaf area index-based surface energy and water balance model
}

\author{
H. Yan ${ }^{\text {a,* }}$, S.Q. Wang ${ }^{\text {b }}$, D. Billesbach ${ }^{\text {c }}$, W. Oechel ${ }^{\text {d, J.H. Zhang }}{ }^{\text {e }}$, T. Meyers ${ }^{\text {f }}$, T.A. Martin ${ }^{\text {g }}$, R. Matamala ${ }^{\text {h, }}$ \\ D. Baldocchi ${ }^{i}$, G. Bohrer ${ }^{j}$, D. Dragoni ${ }^{k}$, R. Scott ${ }^{1}$
}

a National Meteorological Center, China Meteorological Administration, Beijing 100081, China

b Institute of Geographic Sciences and Natural Resources Research, Chinese Academy of Sciences, Beijing 100101, China

c Department of Biological Systems Engineering, University of Nebraska, NE 68583-0726, USA

d Biology Department, San Diego State University, CA 92182-4614, USA

e Institute of Agricultural Meteorology, Chinese Academy of Meteorological Sciences, Beijing 100081, China

${ }^{\mathrm{f}}$ Atmospheric Turbulence and Diffusion Division, NOAA/ARL, TN 37831-2456, USA

g School of Forest Resources and Conservation, University of Florida, Gainesville, FL 32611-0410, USA

h Biosciences Division, Argonne National Laboratory, IL 60439, USA, USA

i Department of Environmental Science, Policy EManagement, University of California, Berkeley, CA 94720-3110, USA

j Department of Civil, Environmental and Geodetic Engineering, Ohio State University, OH 43210, USA

k Department of Geography, Indiana University, IN 47405, USA

${ }^{1}$ USDA-ARS Southwest Watershed Research Center, AZ 85719-1596, USA

\section{A R T I C L E I N F O}

\section{Article history:}

Received 25 October 2011

Received in revised form 3 June 2012

Accepted 3 June 2012

Available online 10 July 2012

\section{Keywords:}

Evapotranspiration

Air relative humidity

Stomatal conductance

Canopy transpiration

Soil evaporation

Soil water balance model

Eddy covariance

\begin{abstract}
A B S T R A C T
Studies of global hydrologic cycles, carbon cycles and climate change are greatly facilitated when global estimates of evapotranspiration $(E)$ are available. We have developed an air-relative-humidity-based two-source (ARTS) $E$ model that simulates the surface energy balance, soil water balance, and environmental constraints on $E$. It uses remotely sensed leaf area index $\left(L_{\mathrm{ai}}\right)$ and surface meteorological data to estimate $E$ by: 1$)$ introducing a simple biophysical model for canopy conductance $\left(G_{\mathrm{c}}\right)$, defined as a constant maximum stomatal conductance $g_{\text {smax }}$ of $12.2 \mathrm{~mm} \mathrm{~s}^{-1}$ multiplied by air relative humidity $\left(R_{\mathrm{h}}\right)$ and $\left.L_{\mathrm{ai}}\left(G_{c}=g_{\mathrm{s} \max } \times R_{h} \times L_{\mathrm{ai}}\right) ; 2\right)$ calculating canopy transpiration with the $G_{\mathrm{c}}$-based Penman-Monteith (PM) E model; 3) calculating soil evaporation from an airrelative-humidity-based model of evapotranspiration (Yan \& Shugart, 2010); 4) calculating total $E\left(E_{0}\right)$ as the sum of the canopy transpiration and soil evaporation, assuming the absence of soil water stress; and 5) correcting $E_{0}$ for soil water stress using a soil water balance model.

This physiological ARTS E model requires no calibration. Evaluation against eddy covariance measurements at 19 flux sites, representing a wide variety of climate and vegetation types, indicates that daily estimated $E$ had a root mean square error $=0.77 \mathrm{~mm} \mathrm{~d}^{-1}$, bias $=-0.14 \mathrm{~mm} \mathrm{~d}^{-1}$, and coefficient of determination, $\mathrm{R}^{2}=0.69$. Global, monthly, $0.5^{\circ}$-gridded ARTS E simulations from 1984 to 1998, which were forced using Advanced Very High Resolution Radiometer $L_{\mathrm{ai}}$ data, Climate Research Unit climate data, and surface radiation budget data, predicted a mean annual land $E$ of $58.4 \times 10^{3} \mathrm{~km}^{3}$. This falls within the range $\left(58 \times 10^{3}-85 \times 10^{3} \mathrm{~km}^{3}\right)$ estimated by the Second Global Soil Wetness Project (GSWP-2; Dirmeyer et al., 2006). The ARTS E spatial pattern agrees well with that of the global $E$ estimated by GSWP-2. The global annual ARTS $E$ increased by $15.5 \mathrm{~mm}$ per decade from 1984 to 1998, comparable to an increase of $9.9 \mathrm{~mm}$ per decade from the model tree ensemble approach (Jung et al., 2010). These comparisons confirm the effectivity of the ARTS $E$ model to simulate the spatial pattern and climate response of global $E$. This model is the first of its kind among remote-sensing-based PM $E$ models to provide global land $E$ estimation with consideration of the soil water balance.
\end{abstract}

(c) 2012 Elsevier Inc. All rights reserved.

\footnotetext{
* Corresponding author. Tel.: +86 10 58995040; fax: +861062172982. E-mail addresses: yanhaon@yahoo.com.cn (H. Yan), sqwang@igsnrr.ac.cn (SQ. Wang), dbillesbach1@unl.edu (D. Billesbach), oechel@sunstroke.sdsu.edu (W. Oechel), zhangjh@cams.cma.gov.cn (JH. Zhang), tilden.meyers@noaa.gov (T. Meyers), tamartin@ufl.edu (TA. Martin), matamala@anl.gov (R. Matamala), baldocchi@berkeley.edu (D. Baldocchi), bohrer.17@osu.edu (G. Bohrer), ddragoni@indiana.edu (D. Dragoni), russ.scott@ars.usda.gov (R. Scott).
}

\section{Introduction}

As a crucial process in the terrestrial ecosystem connecting atmosphere, vegetation, and soil spheres, land evapotranspiration $(E)$ is an important component of the water and energy cycles, and plant transpiration is driven by the same stomatal conductance term that governs carbon cycle. Global $E$ consumes more than $50 \%$ of absorbed solar energy (Trenberth et al., 2009), and returns about $60 \%$ of annual land 
precipitation to the atmosphere (Oki \& Kanae, 2006). Much evidence, mainly drawn from precipitation and runoff datasets, has confirmed the modification of the hydrologic cycle (Alkama et al., 2011; Huntington, 2006; Labat et al., 2004).

Direct observational evidence of this intensification of global land $E$ is, unfortunately, lacking because there are only about 400 flux stations worldwide and their temporal records are very short (Huntington, 2006; Jung et al., 2010). However, large-scale $E$ estimation is required for answering questions related to climate change. Climate change is expected to increase the global available renewable freshwater resources, but the increasing probability of drought and changes to regional precipitation patterns may offset this effect and lead to water stresses in many regions (Oki \& Kanae, 2006). Since leaf stomata control the exchange of water and carbon between vegetation and atmosphere, and high stomatal conductance leads to higher transpiration and photosynthesis, an understanding of global $E$ variation will help to elucidate the effects of climate change on biogeochemical cycling (Dang et al., 1997; Huntington, 2006; Jarvis, 1976; Kelliher et al., 1995; Nemani \& Running, 1989; Shugart, 1998).

The surface energy balance partitions the available energy $\left(R_{\mathrm{n}}-G\right)$ between turbulent heat fluxes ( $\lambda E$ and $H)$ :

$\lambda E=R_{\mathrm{n}}-G-H$,

where $\lambda E$ is latent heat flux ( $\lambda$ is the latent heat of vaporization, and $E$ is evapotranspiration), $R_{\mathrm{n}}$ is net radiation, $G$ is ground heat flux, and $H$ is sensible heat flux. $E$ is mainly controlled by three factors: available water, available energy, and conductivity of the ecosystem to water vapor (Batra et al., 2006).

Satellite remote sensing can supply temporally and spatially continuous observations of key biophysical variables of the land surface, such as $L_{\mathrm{ai}}$, vegetation index (VI), albedo, land surface temperature, and emissivity. It has ushered in a new era for the development of land $E$ models (Cleugh et al., 2007; Fisher et al., 2008; Leuning et al., 2008; Mu et al., 2007, 2011; Nagler et al., 2005; Su, 2002; Wang \& Liang, 2008). There are two principal types of remote sensing $E$ models: empirical and physical.

\section{Empirical $E$ models}

These models often apply statistical regression to estimate $E$, using satellite VI and other meteorological data, such as air temperature and surface net radiation (Nagler et al., 2005; Wang \& Liang, 2008). More recently, Jung et al. (2010) developed a model tree ensemble (MTE) approach that predicts global land $E$ based on a set of explanatory variables (remote sensing-based fraction of absorbed photosynthetically active radiation data, and surface meteorological data), according to model trees constructed from point-wise $E$ measurements at FLUXNET observing sites. Empirical $E$ models need calibration to adapt to the local climate and ecosystem, and often require re-calibration as climate conditions change.

\section{Physical E models}

Physical $E$ models use different biophysical metrics, derived from remote sensing. They can be further classified into two types:

(1) Energy balance $E$ models. They estimate instantaneous $E$ rates as a residual of the land surface energy balance using thermal infrared temperature as the most important input, combined with other data. Examples of this type include the Surface Energy Balance Algorithm for Land (SEBAL; Bastiaanssen et al., 1998), the Surface Energy Balance System (SEBS; Su, 2002), and the Two-Source Energy Balance model (TSEB; Kustas \& Norman, 1999; Norman et al., 1995). In addition, the triangle method uses the slope of remote sensing surface temperature to VI to estimate E (Moran et al., 1994; Nemani \& Running,
1989; Nishida et al., 2003). An advantage of such models is that they do not require precipitation and soil texture data as input. A disadvantage is that they require clear sky conditions, because thermal infrared radiation cannot penetrate cloud. They cannot therefore be applied to cloudy days, and as instantaneous $E$ models, they need gap-filling techniques to estimate daily $E$ from instantaneous $E$ (Anderson et al., 2007; Ryu et al., 2012).

(2) Surface conductance-based $E$ models. These were developed from the Penman-Monteith (PM) combination equation (Monteith, 1965), which incorporates the effects of both vegetation physiology and evaporative demand on $E$. Remote sensing-retrieved $L_{\mathrm{ai}}$ can be used for scaling stomata conductance to surface conductance or canopy conductance for large-scale application of the PM equation (Allen, 1998; Cleugh et al., 2007; Leuning et al., 2008; Mu et al., 2007, 2011; Shuttleworth \& Wallace, 1985). The PM model is defined as

$E=\frac{\Delta A+\rho C_{\mathrm{p}} D G_{a}}{\Delta+\gamma\left(1+G_{a} / G_{s}\right)}$

where $A=R_{\mathrm{n}}-G$ is the available energy; $R_{\mathrm{n}}$ is net radiation; $G$ is soil heat flux; $\Delta$ is the gradient of the saturated vapor pressure to air temperature; $\gamma$ is the psychrometric constant; $\rho$ is the density of air; $C_{\mathrm{p}}$ is the specific heat of air at constant pressure; $G_{\mathrm{a}}$ is the aerodynamic conductance; $G_{s}$ is the surface conductance accounting for transpiration from the vegetation and evaporation by the soil; and $D=e_{\mathrm{s}}-e_{\mathrm{a}}$ is the vapor pressure deficit of the air, in which $e_{s}$ is the saturation water vapor pressure at air temperature and $e_{\mathrm{a}}$ is the actual water vapor pressure. Conductance is the inverse of resistance.

Because the PM model has a single-layer or 'big leaf' assumption and $G_{s}$ is often calculated from $L_{\mathrm{ai}}$ (Table 1; Allen, 1998; Cleugh et al., 2007), soil evaporation is assumed small and is often neglected in the model (Cleugh et al., 2007). However, studies show that where the fractional vegetation cover is small, the surface conductance $G_{s}$ should include the effects of evaporation from the soil surface (Allen, 1998). Field experiments during periods with plentiful soil water, adequate light, high relative humidity $\left(R_{\mathrm{h}}\right)$ and moderate temperature further indicate that $G_{\mathrm{s}}$ does not change linearly with $L_{\mathrm{ai}}$. This is because of the compensating decrease in plant transpiration and increase in soil evaporation with decreasing $L_{\mathrm{ai}}$ (Kelliher et al., 1995). Moreover, water stress factors

Table 1

Summary of surface conductance $G_{\mathrm{s}}$ models and canopy conductance $G_{\mathrm{c}}$ models used in the frame of Penman-Monteith model.

\begin{tabular}{|c|c|c|}
\hline Conductance model & $\begin{array}{l}\text { Coefficient } \\
\left(\mathrm{mm} \mathrm{s}^{-1}\right)\end{array}$ & Citation \\
\hline${ }^{\mathrm{a}} G_{s}=G_{\mathrm{s} 1} \times 0.5 L_{\mathrm{ai}}$ & $G_{\mathrm{s} 1}=10$ & Allen (1998) \\
\hline${ }^{\mathrm{b}} G_{\mathrm{s}}=G_{\mathrm{L}} \times L_{\mathrm{ai}}+G_{\mathrm{s}, \min }$ & $G_{L}=1.9-2.5$ & Cleugh et al. (2007) \\
\hline${ }^{\mathrm{c}} G_{c}=\mathrm{g}_{\mathrm{ST}} \times 2 L_{\mathrm{ai}}$ & $g_{\mathrm{ST}}=2.5$ & $\begin{array}{l}\text { Shuttleworth and } \\
\text { Wallace (1985) }\end{array}$ \\
\hline${ }^{\mathrm{d}} G_{c}=g_{s} \times \mathrm{m}\left(T_{\min }\right) \times \mathrm{m}(D) \times L_{\mathrm{ai}}$ & $g_{s}=2.5-7$ & Mu et al. (2011) \\
\hline${ }^{\mathrm{e}} G_{c}=\frac{g_{s} \max }{0.6} \ln \left[\frac{Q_{h}+Q_{50}}{Q_{h} \times \exp \left(-0.6 \times L_{a i}+Q_{50}\right)}\right]$ & $g_{\text {smax }}=8$ & Kelliher et al. (1995) \\
\hline$G_{c}=\frac{g_{\text {smax }}}{0.6} \ln \left[\frac{Q_{\mathrm{h}}+Q_{50}}{Q_{\mathrm{h}} \times \exp \left(-0.6 \times L_{\mathrm{ai}}\right)+Q_{50}}\right]\left[\frac{1}{1+D / D 50}\right]$ & $g_{\text {smax }}=2-15$ & Leuning et al. (2008) \\
\hline$G_{C}=g_{s \max } \times \exp (-2.5 D) \times L_{\mathrm{ai}}$ & Variable $g_{\text {smax }}$ & $\begin{array}{l}\text { Landsberg and Waring } \\
\text { (1997) }\end{array}$ \\
\hline$G_{c}=g_{s \max } \times R_{h} \times L_{\mathrm{ai}}$ & $g_{\text {smax }}=12.2$ & This study \\
\hline \multicolumn{3}{|c|}{$\begin{array}{l}\text { a } G_{\mathrm{s} 1} \text { is the bulk stomatal conductance of the well-illuminated leaf. } \\
\text { b } G_{\mathrm{L}} \text { is the mean surface conductance and } G_{\mathrm{s}, \mathrm{min}} \text { is the surface conductance control- } \\
\text { ling soil evaporation and the conductance through the leaf cuticle. } \\
{ }^{\mathrm{c}} g_{\mathrm{ST}} \text { is the mean stomatal conductance. } \\
\text { d } g_{\mathrm{s}} \text { is the mean potential stomatal conductance, } \mathrm{m}\left(T_{\min }\right) \text { and } \mathrm{m}(D) \text { are multipliers } \\
\text { to reduce potential stomatal conductance by minimum air temperatures }\left(T_{\min }\right) \text { and } \\
D \text {, respectively. }\end{array}$} \\
\hline
\end{tabular}


should also be included in surface conductance $G_{\mathrm{s}}$ to represent the water stress effect, especially under drought conditions. Thus, soil evaporation and the water stress factor are two problems confronting the PM model.

To more accurately simulate surfaces including partially vegetated surface, two-source $E$ models have been proposed which treat total $E$ as a composite of vegetation transpiration and soil evaporation (Leuning et al., 2008; Mu et al., 2007, 2011; Shuttleworth \& Wallace, 1985):

$E=E_{\mathrm{c}}+E_{\mathrm{s}}$

where $E$ is the total evapotranspiration, $E_{\mathrm{c}}$ is transpiration from the plant canopy, and $E_{\mathrm{s}}$ is soil evaporation. $E_{\mathrm{c}}$ was often calculated from equations of the PM type, with regard to canopy conductance (Landsberg \& Waring, 1997; Leuning et al., 2008; Mu et al., 2011; Shuttleworth \& Wallace, 1985; Zhang et al., 2010b). $E_{\mathrm{s}}$ was also derived from equations of the PM type, with consideration of soil conductance in some $E$ models (Mu et al., 2011; Shuttleworth \& Wallace, 1985; Zhang et al., 2010a). Leuning et al. (2008) suggested calculating soil evaporation $E_{\mathrm{s}}$ from equations of the equilibrium $E$ type.

Recent studies by Cleugh et al. (2007), Leuning et al. (2008), Zhang et al. (2008), and Mu et al. (2007, 2011) suggest that the stomatal conductance-based PM approach provides a biophysical framework of great potential for estimating $E$ at variable spatial and temporal scales, with the advantage of applicability to all sky conditions.

This paper presents an $E$ model called air-relative-humidity-based two-source (ARTS) E model for explicitly considering both plant transpiration and soil evaporation. The plant transpiration model follows the PM framework, and builds on important findings on the relationship between $R_{\mathrm{h}}$ and evaporation efficiency (Yan \& Shugart, 2010) and between $R_{\mathrm{h}}$ and stomatal conductance (Ball et al., 1987; Collatz et al., 1991), in which canopy conductance is defined as a function of $R_{\mathrm{h}}$ and $L_{\mathrm{ai}}$. It is different from previous canopy conductance models that often depend on vapor pressure deficit $(D)$, additional meteorological factors, and $L_{\mathrm{ai}}$ (Leuning et al., 2008; Mu et al., 2007, 2011). For soil evaporation, an $R_{\mathrm{h}}$-corrected Priestley-Taylor model (Yan \& Shugart, 2010 ) is adopted. The model here substantially improves on recent studies, by considering the effect of soil water stress on $E$ through the use of a soil water balance (SWB) model. Leuning et al. (2008) suggested a soil moisture factor $f$, potentially derived from active or passive remote sensing, to correct soil evaporation without regard to the impact of soil water deficit on plant transpiration. Cleugh et al. (2007), Fisher et al. (2008), and Mu et al., 2007, 2011 substituted an air-moisture index for soil-water stress, under an assumption that surface air moisture can reflect variations in soil moisture. However, it is not certain to which degree does soil moisture controls the surface air moisture, and hence $D$ (Vinukollu et al., 2011).

The ARTS $E$ model requires inputs of $L_{\mathrm{ai}}$, net radiation, $R_{\mathrm{h}}$, air temperature, wind speed, canopy height, precipitation, and maximum soil available water content $\left(M_{\mathrm{awc}}\right)$ as model parameters. Model details are given in five parts: (1) model development, especially the building of an air $R_{\mathrm{h}}$ and $L_{\mathrm{ai}}$-based canopy conductance model, and the development of the SWB model; (2) description of remote sensing and meteorological datasets and data pre-processing methods; (3) evaluation of the model at 19 flux tower sites within different ecosystems; (4) assessment of global estimates of land $E$ by comparison with other studies; (5) discussion and potential use of the model for $E$ estimation at large spatial scales.

\section{Evapotranspiration algorithm}

We propose a two-source $E$ model to calculate actual $E$, in two steps. The first is to estimate plant transpiration and soil evaporation using respective equations, under the assumption of plentiful soil water. The second is to account for the effects of soil water stress, using a SWB model. The main improvements to the PM model in this study are explicit consideration of soil water stress impact on $E$.

Naturally, the available energy $A$ is partitioned to two parts: the soil part $\left(A_{\mathrm{s}}\right)$ and canopy part $\left(A_{\mathrm{c}}\right)$ following:

$A_{\mathrm{s}}=A \exp \left(-k_{\mathrm{A}} L_{\mathrm{ai}}\right)$

$A_{\mathrm{c}}=A-A_{\mathrm{s}}$,

where $A_{\mathrm{c}}$ and $A_{\mathrm{s}}$ are the parts of the available energy $(A)$ that are absorbed by the canopy and by the soil, respectively, and $k_{\mathrm{A}}$ is an extinction coefficient that equals 0.6 (Impens \& Lemeur, 1969). A was set to the net radiation $R_{\mathrm{n}}$ here, because soil heat flux $G$ can be ignored for daily and longer time steps in the calculation of $E$ (Allen, 1998). More details are provided below.

\subsection{Canopy transpiration $E_{c}$ and canopy conductance $G_{c}$}

The canopy transpiration $\left(E_{\mathrm{c}}\right)$ model is based on the PM model (Monteith, 1965), but available energy $(A)$ and surface conductance $\left(G_{\mathrm{s}}\right)$ in that model are replaced by the canopy-absorbed available energy $\left(A_{\mathrm{c}}\right)$ and canopy conductance $\left(G_{\mathrm{c}}\right)$ :

$E_{\mathrm{c}}=\frac{\Delta A_{\mathrm{c}}+\rho C_{\mathrm{p}} D G_{a}}{\Delta+\gamma\left(1+G_{\mathrm{a}} / G_{c}\right)}$

Since stomata play a dominant role in regulating the amount of water transpired by vegetation that in turn affects photosynthesis, Jarvis (1976) presented a widely adopted stomatal conductance theory, in which stomatal conductance $\left(g_{\text {sc }}\right)$ can be obtained as a result of complete expression of the influence of all environmental variables without any synergistic interactions:

$g_{s c}=f_{1}(Q) f_{2}(T) f_{3}(D) f_{4}(\psi) f_{5}(C)$,

where $f_{1}, f_{2}, f_{3}, f_{4}$, and $f_{5}$ are functions of absorbed solar radiation $(Q)$, leaf temperature $(T), D$, leaf water potential $(\psi)$, and $\mathrm{CO}_{2}$ concentration (C). This equation describes a complex response of stomata to individual environmental variables. Further leaf gas-exchange measurements indicate that increasing leaf water deficits reduce $g_{\text {sc }}$ (Jarvis, 1976). Since leaf water potential is not operationally measured, soil water deficit often substitutes for it within transpiration estimation.

$L_{\mathrm{ai}}$ has been commonly used to scale $g_{\mathrm{sc}}$ at the leaf level to wholecanopy conductance $\left(G_{c}\right)$. Parameterization of stomatal conductance shows large differences between $E_{\mathrm{c}}$ models (Landsberg \& Waring, 1997; Leuning et al., 2008; Mu et al., 2011; Shuttleworth \& Wallace, 1985), and only a subset of the environmental variables proposed by Jarvis (1976) are considered in calculating stomatal conductance in many $E$ models (Table 1). Leuning et al. (2008) considered the impacts of short-wave radiation $\left(Q_{h}\right)$ and $D$. Landsberg and Waring (1997) only included the stress factor $D$, whereas Mu et al. (2011) considered the effect of $D$ and minimum air temperature $\left(T_{\min }\right)$. Experiments by Yu et al. (1996) also indicate that stomatal conductance may be obtained with the two variables of solar radiation and $D$ in the absence of critical environmental change, such as drought. The aforementioned $g_{\text {sc }}$ models all consider the responses of stomatal conductance to $D$ within the framework of the PM model, i.e., atmospheric humidity deficit is considered the most important stress factor in those models. Since soil water content is not operationally observed in practice, it is hard to parameterize soil water content directly in the stomatal conductance model, and hence soil water stress has been neglected in recent transpiration models (Table 1). Soil water deficit is considered in the SWB section, later in this paper.

Since air $R_{\mathrm{h}}$, defined as $e_{\mathrm{a}}$ divided by $e_{\mathrm{s}}$, is also capable of representing the humidity deficit of air, there are arguments about the choice between $R_{\mathrm{h}}$ and $D$ in $E$ or stomatal conductance estimation. Niyogi and Raman (1997) indicated that the $D$ and $R_{\mathrm{h}}$ variables used 
in stomatal conductance schemes yield similar results for routine meteorological application. Some studies (Leuning, 1995; Wang et al., 2009) show that demand for water vapor by the atmosphere from the leaves depends on the difference in partial pressure between leaves and the atmosphere, not on relative humidity, based on correlation analysis of canopy conductance and $D$. However, analysis of field measurements at flux sites (Yan \& Shugart, 2010) shows that $D$ is dependent on available energy $A$, and compared with $D, R_{\mathrm{h}}$ is more closely related with evaporation fraction $\mathrm{EF}$, defined as $E$ divided by available energy $A$. Besides, $R_{\mathrm{h}}$ has been proposed to build a semi-empirical model of leaf conductance that links stomatal conductance to leaf photosynthesis, $R_{\mathrm{h}}$, and $\mathrm{CO}_{2}$ concentration at the leaf surface (Ball et al., 1987; Collatz et al., 1991). This method has been successfully used in many land surface models, i.e., the Simple Biosphere Model (SIB2; Sellers et al., 1996), Land Surface Model (Bonan, 1996), and Common Land Model (CLM2; Dai et al., 2004). Another appealing attribute of $R_{\mathrm{h}}$ as a normalized value is that the $R_{\mathrm{h}}$-based stomatal conductance model requires fewer tuning parameters. Thus, we present a canopy conductance model with inputs of $R_{\mathrm{h}}$ and $L_{\mathrm{ai}}$ within the framework of PM model,

$G_{\mathrm{c}}=g_{s \max } \times R_{\mathrm{h}} \times L_{\mathrm{ai}}$,

where $R_{\mathrm{h}}$ is a unitless fraction, $0-1$, and $g_{\text {smax }}$ is the maximum stomatal conductance assumed to have a value of $12.2 \mathrm{~mm} \mathrm{~s}^{-1}$, which was observed for agricultural crops (Kelliher et al., 1995). Observations of $g_{\text {smax }}$ for natural vegetation constrain its value to a range between 12 , $8.1,8.3,6.3$, and $9.3 \mathrm{~mm} \mathrm{~s}^{-1}$ for temperate grassland, conifer forest, eucalypt forest, temperate deciduous forest, and tropical rainforest, respectively (Kelliher et al., 1995). As the maximum leaf conductance of $g_{\text {smax }}$ only occurs in optimum conditions with unstressed, well-illuminated leaves (Körner, 1994), we consider $12 \mathrm{~mm} \mathrm{~s}^{-1}$ is more reasonable for $g_{\text {smax }}$ of natural vegetation because the optimum conditions seldom occurred in the field (Chen et al., 1999). In the ARTS model, the highest maximum of $g_{\text {smax }}$, observed in crops, is adopted as a practical approximation rather than a value based on the average $g_{\text {smax }}$ in different ecosystems or an ecosystem-dependent parameter.

The aerodynamic conductance $\left(G_{\mathrm{a}}\right)$ is calculated from the equation (Monteith \& Unsworth, 1990)

$G_{a}=\frac{k^{2} u_{\mathrm{z}}}{\ln \left(\frac{z_{\mathrm{m}}-d}{z_{\mathrm{om}}}\right) \ln \left(\frac{z_{\mathrm{h}}-d}{z_{\mathrm{oh}}}\right)}$,

where $z_{\mathrm{m}}$ is the height of wind measurement, $z_{\mathrm{h}}$ is the height of humidity measurement, $d$ is the zero plane displacement height, $z_{\mathrm{om}}$ is the roughness length governing momentum transfer, $z_{\mathrm{oh}}$ is the roughness length governing heat and vapor transfer, $k$ is von Karman's constant (0.41) and $u_{\mathrm{z}}$ is wind speed at height $z$. The variables $d, z_{\mathrm{om}}$ and $z_{\mathrm{oh}}$ are calculated from the empirical equations $d=(2 / 3) h, z_{\mathrm{om}}=0.123 \mathrm{~h}$ and $z_{\mathrm{oh}}=0.1 \mathrm{z}_{\mathrm{om}}$, where $h$ is the canopy height (Allen, 1998).

\subsection{Soil evaporation $E_{s}$}

We present a soil evaporation equation modified from the air- $\mathrm{RH}-$ based model of evapotranspiration (ARM-ET; Yan \& Shugart, 2010):

$E_{\mathrm{s}}=1.35 R_{\mathrm{h}} \frac{\Delta A_{\mathrm{s}}}{\Delta+\gamma}$

The ARM-ET model scales Priestley and Taylor (1972) equilibrium $E$ to actual $E$, using $R_{\mathrm{h}}$ as a complementary relationship coefficient. Validation at 14 independent flux sites within different climates and vegetation types shows that ARM-ET had an $\mathrm{R}^{2}=0.71$, root mean square error $($ RMSE $)=23.62 \mathrm{~W} \mathrm{~m}^{-2}$, and bias $=8.02 \mathrm{~W} \mathrm{~m}^{-2}$. The $E_{\mathrm{s}}$ model in this study differs from the RS-PM model (Mu et al., 2007), which defines actual soil evaporation as the product of a complementary relationship coefficient of $R_{\mathrm{h}}{ }^{(D / 100)}$ and potential soil evaporation derived from the PM model. The impact of soil water deficit is considered in the SWB section of this paper.

\subsection{Total evapotranspiration $E_{0}$ for well-watered surface}

$E_{0}$ represents evapotranspiration for well-watered surface:

$E_{0}=\frac{\Delta A_{\mathrm{c}}+\rho C_{\mathrm{p}} D G_{a}}{\Delta+\gamma\left(1+G_{\mathrm{a}} / G_{c}\right)}+1.35 R_{\mathrm{h}} \frac{\Delta A_{\mathrm{s}}}{\Delta+\gamma}$

\subsection{Soil water correction using soil water balance model}

As mentioned above, $E_{0}$ equals actual $E\left(E_{\mathrm{a}}\right)$ only for a well-watered surface. However, many studies have revealed that $E$ decreases when soil becomes dry, that is, stomatal conductance and $E$ are strongly affected by soil water deficit in a dry environment (Jarvis, 1976; Saugier \& Katerji, 1991). Thus, a correction to $E_{0}$ is required for a water-stressed surface.

SWB model is an approach widely applied to correct $E_{0}$ and produce $E_{\mathrm{a}}$ (Allen, 1998; Landsberg \& Waring, 1997; Thornthwaite \& Mather, 1955). The SWB model presented here is based on the ThornthwaiteMather approach (Thornthwaite \& Mather, 1955). However, because of its unreliable results under dry conditions (Chen et al., 2005), we replaced the temperature-based potential $E$ used in that approach with the $E_{0}$ model (Eq. (11)). The SWB model requires as inputs precipitation, $E_{0}$, air temperature, and $M_{\mathrm{awc}}$. Its outputs are $E_{\mathrm{a}}$, soil water content, and runoff. Precipitation is first divided into rainfall and snowfall using a temperature threshold of $0^{\circ} \mathrm{C}$, and snowfall is added to the snowpack. Snowmelt from snowpack is calculated using a temperature-based snowmelt function. Rainfall and snowmelt contribute to soil water content. When $E_{0}$ is lower than water input, $E_{\mathrm{a}}$ proceeds at a rate of $E_{0}$, and the excess recharges soil water storage. If the soil water content reaches its available water capacity, it remains at a constant value of $M_{\mathrm{awc}}$, and the excess water forms runoff. However, when $E_{0}$ is greater than water input, $E_{\mathrm{a}}$ equals the water input plus a fraction extracted from soil water, caused by this soil water deficit condition. Soil water loss becomes more difficult as the soil becomes dry, which can be described by a soil water retention function suggested by Thornthwaite and Mather (1955). The principal equations of the SWB can be summarized as follows.

$$
\begin{aligned}
& \frac{d W}{d t}=P-E_{\mathrm{a}}-R_{0} \\
& P=R_{\text {ain }}+S_{\text {now }} \times S_{\mathrm{f}} \\
& S_{\mathrm{f}}=\left\{\begin{array}{ll}
0 & T_{\mathrm{a}} \leq 0^{\circ} \mathrm{C} \\
0.2 T_{a} & 0^{\circ} \mathrm{C}<T_{\mathrm{a}} \leq 5^{\circ} \mathrm{C} \\
1 & T_{\mathrm{a}}>5^{\circ} \mathrm{C}
\end{array}\right\} \\
& E_{\mathrm{a}}= \begin{cases}E_{0} & P \geq E_{0} \\
P+\beta\left(E_{0}-p\right) & P<E_{0}\end{cases} \\
& \beta=\frac{W-W_{\mathrm{p}}}{W_{\mathrm{c}}-W_{\mathrm{p}}},
\end{aligned}
$$

where $W$ is the soil water content $(\mathrm{mm}), d W / d t$ is the change of $W$ over a time $t, P$ is the water input $(\mathrm{mm})$ including precipitation and snowmelt, $E_{\mathrm{a}}$ is actual $E(\mathrm{~mm}), R_{0}$ is runoff ( $\left.\mathrm{mm}\right), R_{\text {ain }}$ is rainfall $(\mathrm{mm}), S_{\text {now }}$ is snowmelt $(\mathrm{mm}), S_{\mathrm{f}}$ is the snowmelt factor, $T_{\mathrm{a}}$ is air temperature $\left({ }^{\circ} \mathrm{C}\right), E_{0}$ is the total $E(\mathrm{~mm})$ for a well-watered surface, defined early in Eq. (11), $\beta$ is the soil water retention function, defined as the ratio of available soil water content $\left(W-W_{\mathrm{p}}\right)$ to $M_{\mathrm{awc}}$ (i.e., $\left.W_{\mathrm{c}}-W_{\mathrm{p}}\right), W_{\mathrm{p}}$ is the soil water content at wilting point $(\mathrm{mm})$, and $W_{\mathrm{c}}$ is the field capacity $(\mathrm{mm})$. 
Table 2

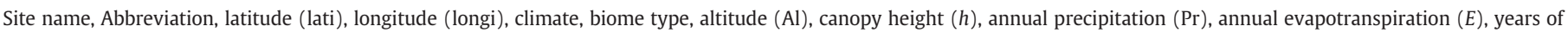
data used for each flux site in this study, and citation.

\begin{tabular}{|c|c|c|c|c|c|c|c|c|c|c|}
\hline Site name & Abbreviation & Lati/Longi & Climate & Biome $^{a}$ & $\mathrm{Al}(\mathrm{m})$ & $h(\mathrm{~m})$ & $\operatorname{Pr}(\mathrm{mm})$ & $E(\mathrm{~mm})$ & Years & Citation \\
\hline ARM SGP Main & SGP & $36.61 /-97.49$ & Temperate & Crop & 314 & 0.5 & 901 & 464 & 2003-2005 & Sheridan et al. (2001) \\
\hline Barrow & Barrow & $71.32 /-156.63$ & Tundra & Grass & 1 & 0.25 & 1140 & 348 & 2004-2005 & Harazono et al. (2003) \\
\hline Bartlett Experimental Forest & Bartlett & $44.06 /-71.29$ & Temperate & $\mathrm{DBF}$ & 272 & 19 & 1300 & 299 & 2004-2005 & Desai et al. (2008) \\
\hline Bondville & Bondville & $40.01 /-88.29$ & Temperate & Crop & 219 & 3 & 990 & 601 & 2001-2004 & Chen et al. (2008) \\
\hline Donaldson & Donaldson & $29.75 /-82.16$ & Subtropical & ENF & 36 & 14 & 1228 & 926 & 2001-2004 & Clark et al. (2004) \\
\hline Fermi Agricultural & FermiA & $41.86 /-88.22$ & & Crop & 225 & 2 & 921 & 580 & $2005-2007$ & Xiao et al. (2008) \\
\hline Fermi Prairie & FermiP & $41.84 /-88.24$ & & Grass & 226 & 1 & 921 & 587 & 2005-2006 & Xiao et al. (2008) \\
\hline Mead Irrigated & MeadI & $41.16 /-96.47$ & Temperate & Crop & 361 & 2.9 & 887 & 632 & $2002-2005$ & Suyker and Verma (2008) \\
\hline Mead Irrigated Rotation & MeadIR & $41.16 /-96.47$ & Temperate & Crop & 362 & 1.83 & 887 & 644 & $2002-2005$ & Grant et al. (2007) \\
\hline Mead Rainfed & MeadR & $41.17 /-96.43$ & Temperate & Crop & 363 & 1.71 & 887 & 583 & 2002-2005 & Grant et al. (2007) \\
\hline Metolius Intermediate Pine & MetoliusI & $44.50 /-121.62$ & Temperate & ENF & 1253 & 14 & 728 & 479 & $2005-2007$ & Thomas et al. (2009) \\
\hline Metolius New Young Pine & MetoliusN & $44.32 /-121.61$ & Temperate & ENF & 1008 & 3.11 & 472 & 323 & 2004-2005 & Irvine et al. (2007) \\
\hline Mize & Mize & $29.76 /-82.24$ & Subtropical & ENF & 43 & 10.1 & 1228 & 942 & 2001-2004 & Clark et al. (2004) \\
\hline Morgan Monroe State Forest & Morgan & $39.32 /-86.41$ & Temperate & DBF & 275 & 27 & 1094 & 513 & $2001-2003$ & Dragoni et al. (2007) \\
\hline Santa Rita Mesquite Savanna & Santa & $31.82 /-110.87$ & Subtropical & Shrub & 1116 & 2.5 & 310 & 302 & 2004-2006 & Scott et al. (2009) \\
\hline Tonzi Ranch & Tonzi & $38.43 /-120.97$ & Mediterranean & Savanna & 177 & 9.41 & 558 & 398 & $2003-2005$ & Ma et al., 2007 \\
\hline Univ. of Michigan Biological Station & UMBS & $45.56 /-84.71$ & Temperate & DBF & 234 & 21 & 750 & 529 & $2001-2003$ & Nave et al. (2011) \\
\hline Vaira Ranch & Vaira & $38.41 /-120.95$ & Mediterranean & Savanna & 129 & 0.55 & 565 & 301 & $2001-2005$ & Ryu et al. (2008) \\
\hline Wind River Crane Site & WindR & $45.82 /-121.95$ & Mediterranean & ENF & 371 & 56.3 & 2223 & 483 & 2001-2002 & Falk et al. (2008) \\
\hline
\end{tabular}

a Deciduous broadleaf forest (DBF), Evergreen needleleaf forest (ENF).

\section{Datasets and pre-processing}

\subsection{Observation data for model evaluation}

ET and meteorological data, measured at 19 AmeriFlux flux-tower sites (Table 2) by the eddy-covariance (EC) method, were used in model evaluation. The EC method is widely accepted for directly measuring heat fluxes (Paw et al., 2000) and is widely applied to global $E$ measurements at flux tower sites in FLUXNET (Baldocchi et al., 2001). The AmeriFlux network is a core part of the global FLUXNET network. It includes sites from North, Central, and South America and continuously observes ecosystem-level exchanges of $\mathrm{CO}_{2}$, water, and energy.

Gap-filled, daily and monthly averaged level-4 EC data (e.g., latent heat flux $\lambda E$, air temperature $T_{\mathrm{a}}$, and precipitation $P$ ) and half-hourly level-3 data (e.g., $R_{\mathrm{h}}$, net radiation $R_{\mathrm{n}}$, and wind speed $u$ ) were downloaded from the AmeriFlux network (ftp://cdiac.ornl.gov/pub/ameriflux/ data). The half-hourly level-3 data were further processed into daily and monthly averaged data, to match the level-4 EC data.

Soil data, including soil depth and texture at the 19 flux sites (Table 3), were downloaded from the Oak Ridge National Laboratory

Table 3

Soil depth $\left(S_{\mathrm{d}}\right)$, soil composition, and soil water characteristics including wilting point $\left(W_{\mathrm{p}}\right)$, field capacity $\left(W_{\mathrm{c}}\right)$, and maximum soil available water content $\left(M_{\mathrm{awc}}\right)$ at nineteen flux sites.

\begin{tabular}{llllcc}
\hline SiteName & $S_{\mathrm{d}}(\mathrm{m})$ & Sand/Silt/Clay $(\%)$ & $W_{\mathrm{p}}(\mathrm{mm})$ & $W_{\mathrm{c}}(\mathrm{mm})$ & $M_{\mathrm{awc}}(\mathrm{mm})$ \\
\hline SGP & 0.25 & $29 / 28 / 43$ & 50 & 99 & 49 \\
Barrow & 0.4 & $47 / 30.6 / 22.4$ & 48 & 112 & 64 \\
Bartlett & 1.02 & $73 / 23 / 4$ & 81 & 233 & 152 \\
Bondville & 1.0 & $5 / 70 / 25$ & 120 & 348 & 228 \\
Donaldson & 3.0 & $99 / 0 / 1$ & 210 & 540 & 330 \\
FermiA & 1.0 & $7.8 / 55.2 / 37$ & 160 & 385 & 225 \\
FermiP & 1.0 & $12.2 / 53 / 34.8$ & 180 & 410 & 230 \\
MeadI & 1.8 & $37 / 52 / 11$ & 144 & 484 & 340 \\
MeadIR & 1.8 & $33 / 55 / 12$ & 144 & 497 & 353 \\
MeadR & 1.8 & $35 / 57 / 80$ & 144 & 506 & 362 \\
MetoliusI & 0.9 & $67 / 26 / 7$ & 63 & 182 & 119 \\
MetoliusN & 0.7 & $80 / 20 / 0$ & 7 & 116 & 109 \\
Mize & 3.0 & $99 / 0 / 1$ & 210 & 540 & 330 \\
Morgan & 1.0 & $34 / 26 / 40$ & 190 & 377 & 187 \\
Santa & 1.1 & $79.6 / 11 / 9.4$ & 77 & 198 & 121 \\
Tonzi & 0.6 & $37.5 / 45 / 17.5$ & 60 & 168 & 108 \\
UMBS & 1.2 & $92.6 / 6.8 / 0.6$ & 36 & 129 & 93 \\
Vaira & 0.6 & $29.5 / 58 / 12.5$ & 54 & 175 & 121 \\
WindR & 2.0 & $63 / 29.8 / 7.2$ & 200 & 507 & 307 \\
\hline
\end{tabular}

Distributed Active Archive Center (ORNL-DAAC) and used to calculate soil water characteristics. $M_{\mathrm{awc}}$ is required as input to the SWB model, to represent soil water changes. $M_{\mathrm{awc}}$ is defined as

$M_{\mathrm{awc}}=W_{\mathrm{c}}-W_{\mathrm{p}}$

where $M_{\text {awc }}$ is maximum soil available water content (mm). Wilting point $W_{\mathrm{p}}$ and field capacity $W_{\mathrm{c}}$ were calculated from soil depth and soil texture information, i.e., the relative proportion of sand, silt and clay, according to a set of prediction equations developed by Saxton et al. (1986). Table 3 shows that there are large differences in soil water characteristics at the flux sites. For example, the site SGP had the lowest $M_{\text {awc }}(49 \mathrm{~mm})$ because of its shallow soil depth $(0.25 \mathrm{~m})$; Both FermiP and Bondville had $M_{\text {awc }}$ of about $230 \mathrm{~mm}$, twice as much as at Vaira and Tonzi.

The input $L_{\mathrm{ai}}$ data required to compute canopy conductance were obtained from the 1- $\mathrm{km}^{2}$, 8-day MODIS collection 5 FPAR/LAI product (MOD15A2) (Myneni et al., 2002). These were also downloaded from ORNL DAAC as a $7 \times 7 \mathrm{~km}^{2}$ subsets centered on each flux tower. Companion quality control data were used to filter MODIS $L_{\mathrm{ai}}$ data. All poor quality data were deleted and replaced by bilinear interpolation of the nearest reliable data, as suggested by Zhao et al. (2005). Further, 8-day $L_{\mathrm{ai}}$ data were interpolated to daily and averaged to monthly $L_{\mathrm{ai}}$ for model evaluation.

The AmeriFlux EC tower sites (Table 2) represent different climates (Mediterranean, humid continental, and temperate continental), soil types (silt loam and clay loam), and vegetation types (forest, savanna, grassland, and cropland). For instance, the Tonzi site features rocky silt loam, oak/grass savanna, and a Mediterranean climate with a clear change between dry and wet seasons, and almost no precipitation in the dry season (Fig. 1). In summer, the grass is dead from arid conditions and solar radiation, but it grows in winter when precipitation is abundant and the temperature is low. The SGP site represents cropland, a soil type of silty clay loam, and a temperate continental climate with plentiful precipitation year-round (Fig. 2). The FermiP site is covered with silty clay loam and tall grass prairie, with a humid continental climate, plentiful year-round precipitation (Fig. 2) and hot summers. A more detailed description of the flux sites can be found at the website http://public.ornl.gov/ameriflux/site-select.cfm.

\subsection{Global data}

The input global $0.5^{\circ}$ gridded, terrestrial biophysical data, i.e., green LAI, roughness length and zero plane displacement, were derived from 
E
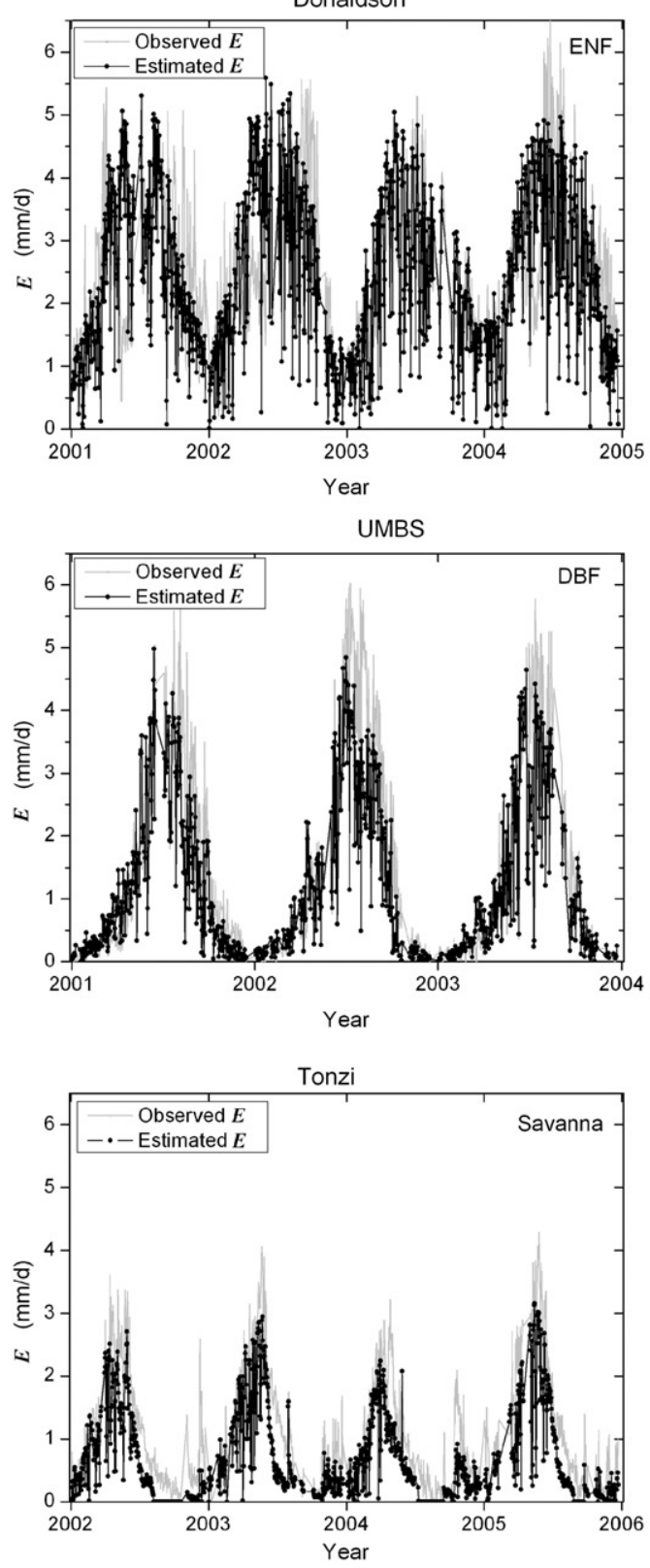
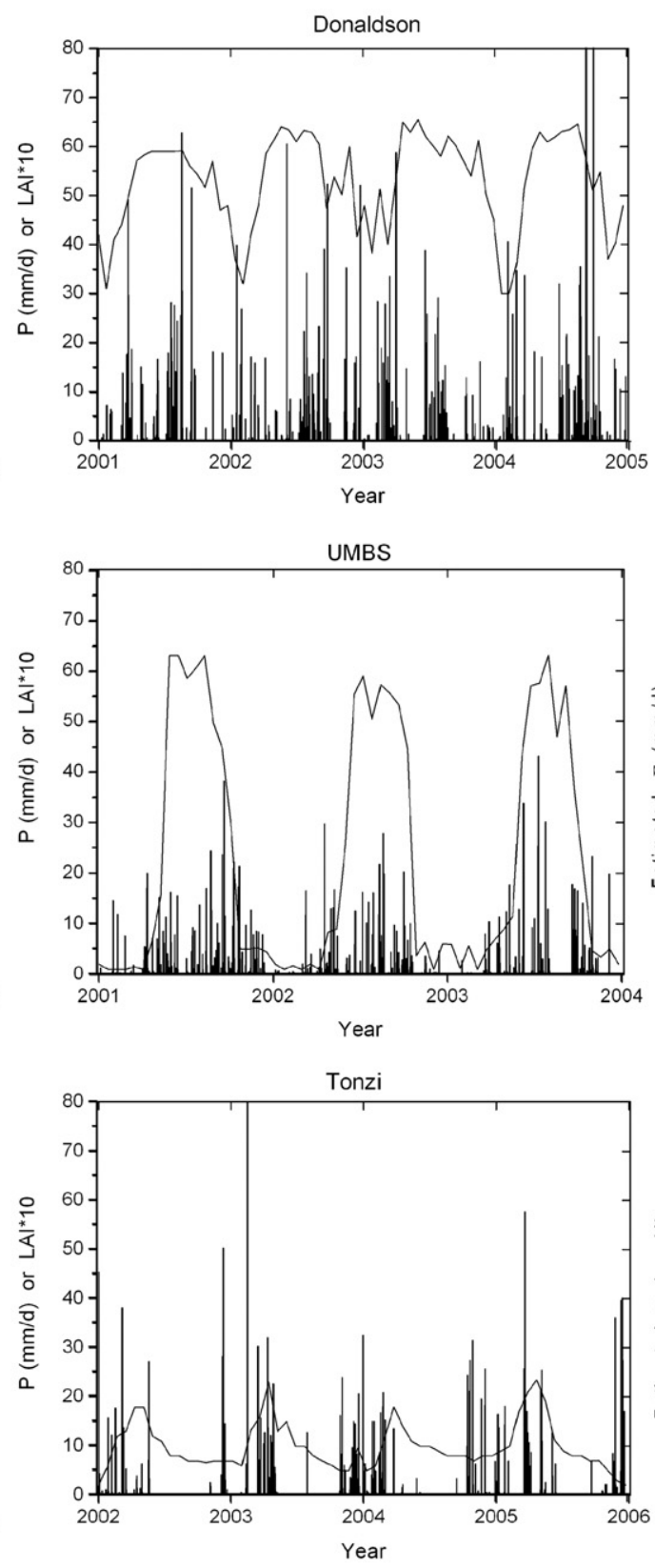

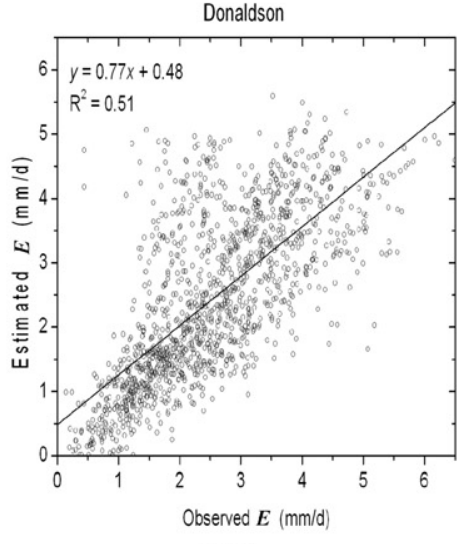

UMBS

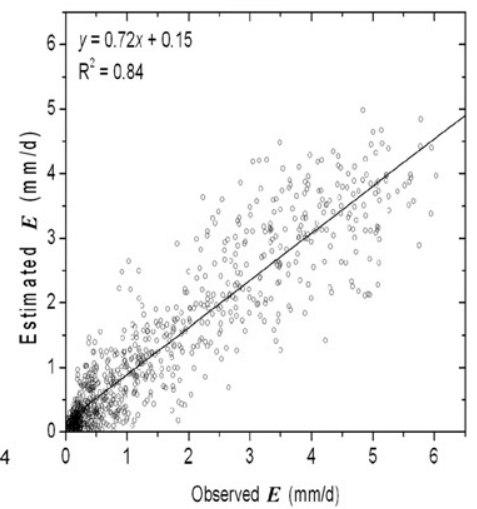

Tonzi

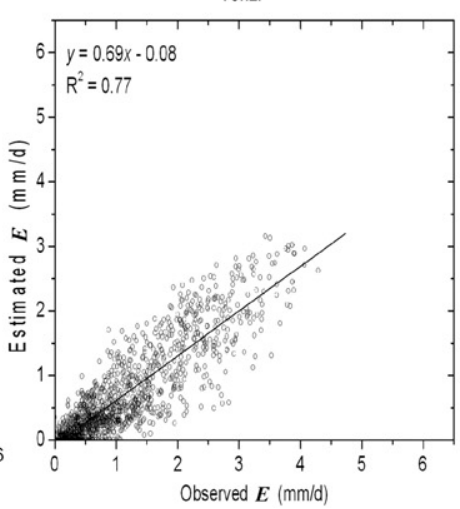

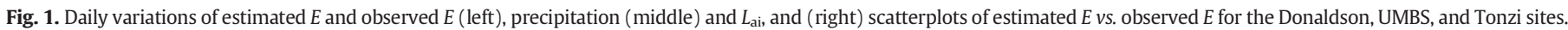

the monthly ISLSCP II FASIR NDVI dataset from the period 1982 to 1998. The Fourier-Adjusted, Sensor and Solar zenith angle-corrected, Interpolated, Reconstructed (FASIR) adjusted NDVI data were calculated from Pathfinder Advanced Very High Resolution Radiometer (AVHRR) Land (PAL) channel 1 and 2 data, and were corrected for bidirectional reflectance distribution function effects, volcanic aerosol, cloud and atmospheric effects, and missing data (Hall et al., 2006; Los et al., 2000). $L_{\mathrm{ai}}$ was derived from NDVI with an assumption that $L_{\mathrm{ai}}$ changes linearly with vegetation fraction (Los et al., 2000). Roughness length and zero plane displacement were calculated from LAI, using the first-order closure model of Sellers et al. (1989). The FASIR biophysical parameters are likely to have errors on the order of $20-30 \%$ of the amplitude of interannual variation (Los et al., 2000; Malmström et al., 1997).

CRU 3.0 climate data is a $0.5^{\circ}$ latitude/longitude, gridded dataset of monthly terrestrial surface climate over the period 1901-2006. The dataset is produced by the Climate Research Unit (CRU) at the University of East Anglia, and comprises seven climate elementsprecipitation, mean temperature, diurnal temperature range, wet- day frequency, vapor pressure, cloud cover and ground-frost frequency (New et al., 2000). The spatial coverage is over all land areas, excluding Antarctica. The construction method ensures strict temporal fidelity. Monthly CRU time-series show month-by-month variations in climate. Because of the unavailability of monthly wind speed data in the CRU 3.0 datasets over the research period, monthly wind speed data from the reanalysis project (Kistler et al., 2001) of the National Centers for Environmental Prediction (NCEP), National Center for Atmospheric Research (NCAR), were used instead.

Surface radiation budget (SRB) data were obtained from the NASA Langley Research Center Atmospheric Sciences Data Center NASA/ GEWEX SRB Project. They were used to characterize surface, top-ofatmosphere, and atmospheric shortwave (SW) and longwave (LW) radiative fluxes, at a precision required to predict transient climate variations and decadal-to-centennial climate trends. The SW and LW SRB datasets were derived on a $1^{\circ} \times 1^{\circ}$ global grid, with quality-check algorithms based on radiative transfer calculations using the Delta-Eddington approximation (Gupta et al., 1992, 2001). Validations against ground 

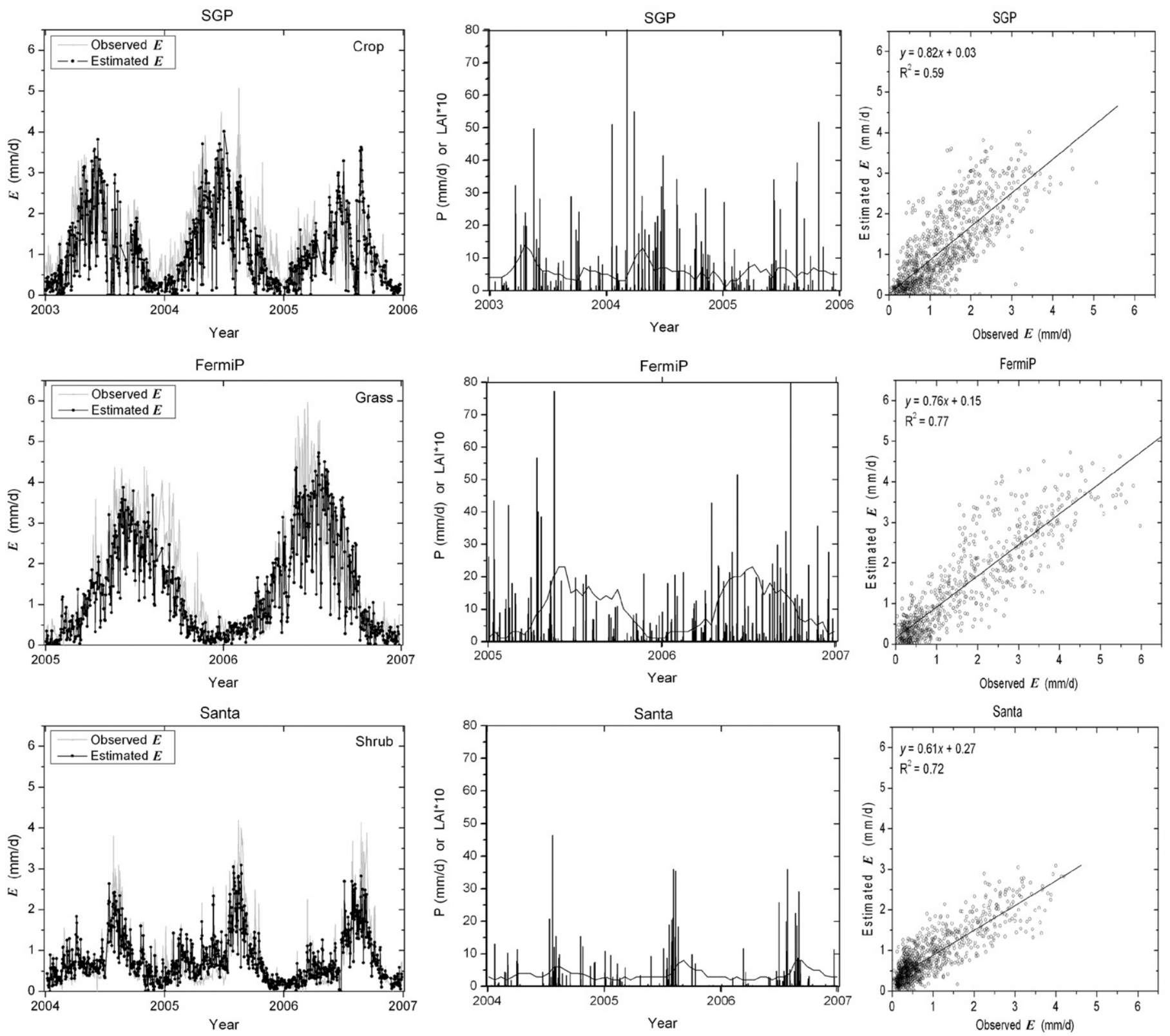

Fig. 2. As in Fig. 1 except for the SGP, FermiP, and Santa sites.

measurements show that monthly averaged SW radiative fluxes have a bias $=-6.7 \mathrm{Wm}^{-2}$ and $\mathrm{RMSE}=18.7 \mathrm{Wm}^{-2}$, whereas LW radiative fluxes have a bias $=3.6 \mathrm{Wm}^{-2}$ and RMSE $=12.8 \mathrm{Wm}^{-2}$. Larger errors were found over snow- or ice-covered surfaces (http://gewex-srb.larc. nasa.gov/common/php/SRB_validation.php).

Global $1^{\circ}$ gridded surfaces of selected soil characteristics, including $M_{\text {awc }}$ for a soil depth of $0-150 \mathrm{~cm}$, developed by the International Geosphere-Biosphere Programme (IGBP), Data and Information Services (DIS), were downloaded from the ORNL-DAAC (http://daac.ornl. gov/).

\section{Results}

\subsection{Model evaluation at 19 flux sites}

Statistics of model performance at the daily scale for all 19 sites (Table 4) show that the ARTS $E$ goodness of fit and error varied from site to site. The slopes of the linear regression of estimated $E$ vs. observed $E$ ranged from 0.58 at Vaira to 1.32 at Bartlett, and the intercepts varied from $-0.08 \mathrm{~mm} \mathrm{~d}^{-1}$ at Tonzi to $0.48 \mathrm{~mm} \mathrm{~d}^{-1}$ at Donaldson. The $E$ model had an average RMSE of $0.75 \mathrm{~mm} \mathrm{~d}^{-1}$ for all sites, ranging from $0.45 \mathrm{~mm} \mathrm{~d}^{-1}$ at Santa to $1.09 \mathrm{~mm} \mathrm{~d}^{-1}$ at Donaldson. An average bias of $-0.11 \mathrm{~mm} \mathrm{~d}^{-1}$ was obtained for all sites, ranging from $-0.46 \mathrm{~mm} \mathrm{~d}^{-1}$ at FermiA to $0.59 \mathrm{~mm} \mathrm{~d}^{-1}$ at Bartlett; underestimation was found at 15 sites and overestimation at only four, i.e., Barrow, Bartlett, Morgan, and WindR. On average, the $E$ model explained $70 \%$ of the variance in estimated $E$ for all sites, ranging from $50 \%$ at WindR to a high of $85 \%$ at Bartlett.

Daily variations of estimated $E$ and observed $E$ at flux sites for available years (Figs. 1 and 2 ) indicate that estimated $E$ successfully simulated the seasonal variation of observed $E$ at six sites, representing six ecosystem types: evergreen needleleaf forest (ENF), deciduous broadleaf forest (DBF), savanna, cropland, grassland, and shrubland (Figs. 1 and 2). These types have large differences in natural environments and vegetation. At opposite moisture extremes are Donaldson and Santa. The former represents a humid environment, with evergreen forest, abundant precipitation of $1228 \mathrm{~mm} \mathrm{yr}^{-1}$, and a high $E$ of $927 \mathrm{~mm} \mathrm{yr}^{-1}$. The latter has a dry environment with deficit precipitation of $310 \mathrm{~mm} \mathrm{yr}^{-1}$ and a lower 
Table 4

Mean $\left(\mathrm{mm} \mathrm{d}^{-1}\right)$, Bias $\left(\mathrm{mm} \mathrm{d}^{-1}\right)$, RMSE $\left(\mathrm{mm} \mathrm{d}^{-1}\right), \mathrm{R}^{2}$, slope and intercept of linear regression equation (estimated $E=k \times$ observed $E+b$ ) of average daily estimated $E v s$. observed $E$ at daily temporal scale.

\begin{tabular}{lllllll}
\hline Site name & Mean & \multicolumn{1}{l}{ Rias } & RMSE & $\mathrm{R}^{2}$ & $k$ & $b$ \\
\hline SGP & 1.08 & -0.18 & 0.63 & 0.59 & 0.82 & 0.03 \\
Barrow & 1.41 & 0.48 & 0.82 & 0.68 & 0.98 & 0.5 \\
Bartlett & 1.44 & 0.59 & 0.85 & 0.85 & 1.32 & 0.31 \\
Bondville & 1.25 & -0.46 & 0.85 & 0.71 & 0.68 & 0.07 \\
Donaldson & 2.37 & -0.09 & 0.93 & 0.51 & 0.77 & 0.48 \\
FermiA & 1.23 & -0.46 & 0.87 & 0.73 & 0.64 & 0.14 \\
FermiP & 1.36 & -0.22 & 0.67 & 0.77 & 0.76 & 0.15 \\
MeadI & 1.43 & -0.33 & 0.92 & 0.80 & 0.62 & 0.32 \\
MeadIR & 1.54 & -0.29 & 0.91 & 0.79 & 0.65 & 0.34 \\
MeadR & 1.38 & -0.33 & 0.85 & 0.78 & 0.64 & 0.27 \\
MetoliusI & 0.83 & -0.39 & 0.66 & 0.6 & 0.67 & 0.01 \\
MetoliusN & 0.89 & -0.01 & 0.44 & 0.64 & 0.8 & 0.16 \\
Mize & 2.46 & -0.12 & 0.75 & 0.66 & 0.77 & 0.45 \\
Morgan & 1.58 & 0.21 & 0.67 & 0.82 & 0.83 & 0.43 \\
Santa & 0.79 & -0.05 & 0.45 & 0.72 & 0.61 & 0.27 \\
Tonzi & 0.68 & -0.42 & 0.61 & 0.77 & 0.69 & -0.08 \\
UMBS & 1.27 & -0.25 & 0.70 & 0.84 & 0.72 & 0.15 \\
Vaira & 0.71 & -0.10 & 0.60 & 0.56 & 0.58 & 0.23 \\
WindR & 1.64 & 0.31 & 0.98 & 0.50 & 1.14 & 0.12 \\
Average & 1.33 & -0.11 & 0.75 & 0.70 & & \\
\hline & & & & & & \\
\hline & & & & & \\
\end{tabular}

$E$ of $303 \mathrm{~mm} \mathrm{yr}^{-1}$. Comparisons of annual observed $E$ with annual precipitation at the Santa site reveal that almost $100 \%$ of the annual precipitation was evaporated into the atmosphere, mainly via soil evaporation. This is because of sparse vegetation with a lower mean $L_{\mathrm{ai}}$ of $0.4 ; E$ is largely controlled by precipitation. At Donaldson, $75 \%$ of the annual precipitation was converted to $E$ mainly in the form of plant transpiration, since there is thick vegetation with a stable, higher $L_{\mathrm{ai}}$ of $\sim 5.1$; $E$ variations are mainly driven by available energy. Tonzi represents a third climate type, with seasonal precipitation; 68\% of annual precipitation $\left(558 \mathrm{~mm} \mathrm{yr}^{-1}\right)$ was turned into $E\left(399 \mathrm{~mm} \mathrm{yr}^{-1}\right)$. In the rainy season, there is abundant precipitation and vegetation with $L_{\mathrm{ai}}$ of $\sim 2$, and plant transpiration governs $E$. In the dry season, there is little precipitation and soil evaporation is strong as a result of sparse vegetation.

There was a strong correlation between estimated and observed $E$ (Figs. 1 and 2). Nonetheless, the $E$ model tended to underestimate the summer peak in estimated daily $E$ at six sites. This might be attributed to missing the summer peak value of daily $L_{\mathrm{a} i}$, which were linearly interpolated from MODIS 8-day-LAI products, and other climatic factors, such as $A, T_{a}$, and $R_{h}$.
The statistics of estimated $E$ vs. observed $E$ at a daily scale (Fig. 3a) showed good agreement for all data from all 19 sites. Linear regression yielded a slope of 0.74 and intercept of $0.24 \mathrm{~mm} \mathrm{~d}^{-1}$. The model accounted for $69 \%$ of the variation in estimated $E$, and underestimated $E$ with a bias $=-0.14 \mathrm{~mm} \mathrm{~d}^{-1}$ and RMSE $=0.77 \mathrm{~mm} \mathrm{~d}^{-1}$.

To evaluate the performance of our model, we compared the above results with previous studies. Our $E$ model performed less well than a two-parameter, surface conductance-based $E$ model (Leuning et al., 2008), which closely fitted observed $E$ for all data from 15 flux sites at daily scale $\left(Y=0.83 X+0.22, \mathrm{R}^{2}=0.80\right)$. Nevertheless, the latter model required site-level optimization of two parameters for the surface conductance, whereas our results were obtained without any site-specific calibration or parameter optimization. Though the different sites and number of sites that were used for evaluation makes the comparison between models performances indirect and qualitative, our model performed better than the improved RS-PM model (Mu et al., 2011), and even the revised RS-PM model (Yuan et al., 2010). The improved RS-PM model had an average RMSE $=0.84 \mathrm{~mm} \mathrm{~d}^{-1}$ and an average $\mathrm{R}^{2}=0.42$ at daily scale, for 46 eddy flux sites. The revised RS-PM model, with three parameters calibrated at 21 sites, had an $\mathrm{R}^{2}=0.68$ at 8-day temporal scale, for 33 evaluation sites.

As with the daily scale, the model performance at monthly scale also varied from site to site (Table 5). The slopes of the linear regression of estimated $E$ vs. observed $E$ range from 0.65 at Vaira to 1.87 at WindR, and the intercepts vary from $-0.74 \mathrm{~mm} \mathrm{~d}^{-1}$ at WindR to $0.68 \mathrm{~mm} \mathrm{~d}^{-1}$ at Donaldson. On average, the $E$ model explained $80 \%$ of the variance in estimated $E$ for all sites, ranging from $45 \%$ at Donaldson to $92 \%$ at UMBS. An average bias of $-0.01 \mathrm{~mm} \mathrm{~d}^{-1}$ was obtained for all sites, ranging from $-0.34 \mathrm{~mm} \mathrm{~d}^{-1}$ at Tonzi to $0.62 \mathrm{~mm} \mathrm{~d}^{-1}$ at Bartlett; underestimation was found at 12 sites and overestimation at only seven. The $E$ model had an average RMSE of $0.57 \mathrm{~mm} \mathrm{~d}^{-1}$ across all sites, ranging from $0.28 \mathrm{~mm} \mathrm{~d}^{-1}$ at Santa to $0.82 \mathrm{~mm} \mathrm{~d}^{-1}$ at Donaldson.

Evaluation at different temporal scales for all data (Fig. 3a and b) showed that ARTS E accuracy increased with temporal scale; the slope $k$ of linear regression also increased, from 0.74 for daily ARTS $E$ to 0.84 for monthly ARTS $E$. Daily estimated $E$ (Fig. 3a) had RMSE = $0.77 \mathrm{~mm} \mathrm{~d}^{-1}$, Bias $=-0.14 \mathrm{~mm} \mathrm{~d}^{-1}$, and $\mathrm{R}^{2}=0.69$; monthly estimated $E$ (Fig. 3b) showed better performance (RMSE $=0.59 \mathrm{~mm} \mathrm{~d}^{-1}$, bias $=$ $-0.05 \mathrm{~mm} \mathrm{~d}^{-1}$, and $\left.\mathrm{R}^{2}=0.77\right)$. Similarly, $\mathrm{Mu}$ et al. (2011) reported poorer statistics of RMSE $=0.84 \mathrm{~mm} \mathrm{~d}^{-1}$ and $\mathrm{R}^{2}=0.42$ at daily scale, whereas Fisher et al. (2008) estimated monthly $E$ with better statistics of $\mathrm{RMSE}=0.53 \mathrm{~mm} \mathrm{~d}^{-1}$ and $\mathrm{R}^{2}=0.90$. The dependence of $E$ model performance on temporal scale was seldom addressed in previous (a) Daily

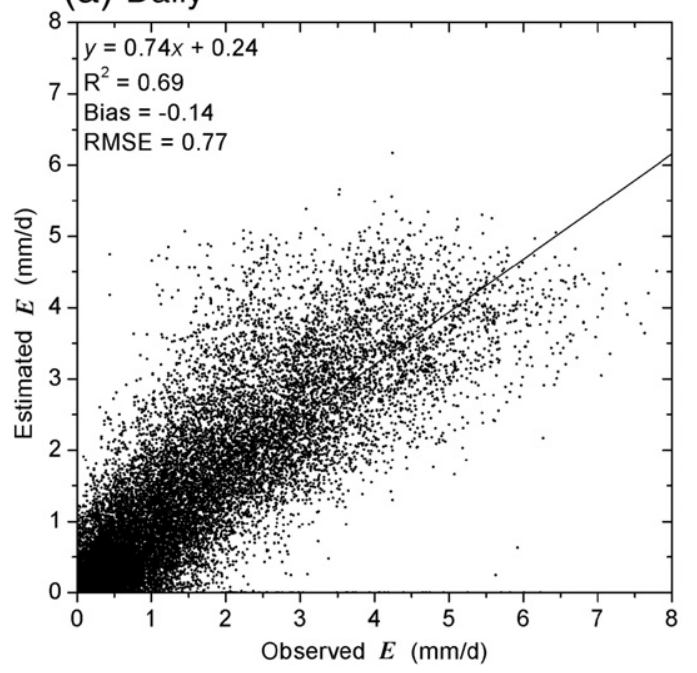

(b) Monthly

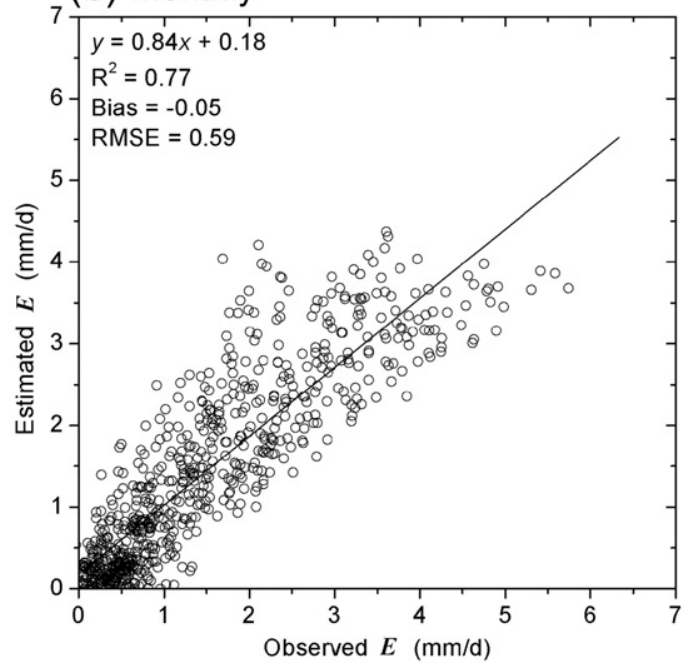

Fig. 3. Scatterplots of daily average estimated $E$ vs. observed $E$ at daily (a) and monthly (b) temporal scales for all sites, all data. 
Table 5

As in Table 4 except for monthly temporal scale.

\begin{tabular}{llllllr}
\hline Abbreviation & Mean & \multicolumn{1}{l}{ Bias } & RMSE & $\mathrm{R}^{2}$ & $k$ & \multicolumn{1}{l}{$b$} \\
\hline SGP & 1.25 & -0.03 & 0.52 & 0.63 & 1.05 & -0.1 \\
Barrow & 1.56 & 0.61 & 0.74 & 0.85 & 1.23 & 0.38 \\
Bartlett & 1.44 & 0.62 & 0.82 & 0.92 & 1.58 & 0.14 \\
Bondville & 1.34 & -0.30 & 0.55 & 0.84 & 0.92 & -0.17 \\
Donaldson & 2.52 & -0.01 & 0.82 & 0.45 & 0.72 & 0.68 \\
FermiA & 1.25 & -0.34 & 0.52 & 0.87 & 0.84 & -0.07 \\
FermiP & 1.49 & -0.12 & 0.51 & 0.83 & 0.83 & 0.14 \\
MeadI & 1.45 & -0.28 & 0.68 & 0.89 & 0.69 & 0.25 \\
MeadIR & 1.54 & -0.23 & 0.65 & 0.87 & 0.72 & 0.26 \\
MeadR & 1.39 & -0.21 & 0.51 & 0.90 & 0.77 & 0.14 \\
MetoliusI & 1.00 & -0.31 & 0.55 & 0.68 & 0.8 & -0.04 \\
MetoliusN & 0.91 & 0.02 & 0.32 & 0.78 & 0.94 & 0.07 \\
Mize & 2.64 & 0.06 & 0.52 & 0.76 & 0.76 & 0.65 \\
Morgan & 1.77 & 0.36 & 0.59 & 0.88 & 0.94 & 0.43 \\
Santa & 0.84 & 0.01 & 0.28 & 0.83 & 0.86 & 0.12 \\
Tonzi & 0.75 & -0.34 & 0.43 & 0.89 & 0.92 & -0.26 \\
UMBS & 1.28 & -0.17 & 0.45 & 0.92 & 0.8 & 0.11 \\
Vaira & 0.79 & -0.03 & 0.59 & 0.52 & 0.65 & 0.25 \\
WindR & 1.74 & 0.42 & 0.81 & 0.88 & 1.87 & -0.74 \\
Average & 1.42 & -0.01 & 0.57 & 0.80 & & \\
\hline
\end{tabular}

studies, so it is recommended to compare $E$ models at the same temporal scale.

One deficiency of this and similar studies is intrinsic to the method of comparison of estimated and observed $E$ values of daily and seasonal variation using linear regression analysis. This approach might give over-confidence in model performance because much of the variation in $E$ is driven by the corresponding variation in available energy. Thus, a more objective test of model skill is to subtract equilibrium evaporation from the estimated and measured $E$ to see how well the $E$ model accounts for the residuals.

$E_{\mathrm{eq}}=\frac{\Delta A}{\Delta+\gamma}$,

where $E_{\text {eq }}$ is the equilibrium evaporation; other variables have the same meaning as in Eq. (2).

Table 6 shows that ARTS E model explained more than 75\% of the variation in the residuals at six sites (i.e., SGP, MetoliusI, MetoliusN, Santa, Tonzi, and Vaira) with limited precipitation of $\sim 589 \mathrm{~mm} \mathrm{yr}^{-1}$, whereas less than $47 \%$ of the variance in the residuals was explained

Table 6

Mean $\left(\mathrm{mm} \mathrm{d}^{-1}\right)$, Bias $\left(\mathrm{mm} \mathrm{d}^{-1}\right)$, RMSE $\left(\mathrm{mm} \mathrm{d}^{-1}\right), \mathrm{R}^{2}$, slope and intercept of linear regression equation (Estimated $E-E_{\mathrm{eq}}=k \times\left(\right.$ Observed $\left.\left.E-E_{\mathrm{eq}}\right)+b\right)$ of average daily estimated $E$ minus $E_{\mathrm{eq}} v s$. observed $E$ minus $E_{\mathrm{eq}}$ at daily temporal scale.

\begin{tabular}{llllllr}
\hline Site name & Mean & \multicolumn{1}{l}{ Bias } & RMSE & $\mathrm{R}^{2}$ & $k$ & \multicolumn{1}{l}{$b$} \\
\hline SGP & -0.61 & -0.18 & 0.63 & 0.75 & 0.73 & -0.30 \\
Barrow & -0.57 & 0.48 & 0.81 & 0.41 & 0.59 & 0.05 \\
Bartlett & -0.35 & 0.59 & 0.85 & 0.41 & 0.37 & 0.00 \\
Bondville & -0.49 & -0.45 & 0.85 & 0.26 & 0.35 & -0.48 \\
Donaldson & -0.08 & -0.09 & 0.95 & 0.10 & 0.09 & -0.09 \\
FermiA & -0.63 & -0.46 & 0.87 & 0.44 & 0.45 & -0.56 \\
FermiP & -0.57 & -0.22 & 0.67 & 0.36 & 0.46 & -0.41 \\
MeadI & -0.54 & -0.33 & 0.92 & 0.25 & 0.28 & -0.48 \\
MeadIR & -0.49 & -0.29 & 0.91 & 0.26 & 0.26 & -0.44 \\
MeadR & -0.56 & -0.33 & 0.85 & 0.28 & 0.33 & -0.48 \\
MetoliusI & -0.67 & -0.39 & 0.66 & 0.76 & 0.68 & -0.48 \\
MetoliusN & -0.95 & -0.01 & 0.44 & 0.83 & 0.85 & -0.16 \\
Mize & -0.33 & -0.12 & 0.74 & 0.18 & 0.39 & -0.25 \\
Morgan & -0.36 & 0.21 & 0.67 & 0.38 & 0.35 & -0.16 \\
Santa & -1.39 & -0.05 & 0.45 & 0.87 & 0.80 & -0.33 \\
Tonzi & -1.76 & -0.42 & 0.61 & 0.93 & 0.98 & -0.45 \\
UMBS & -0.35 & -0.25 & 0.70 & 0.29 & 0.37 & -0.31 \\
Vaira & -1.00 & -0.10 & 0.60 & 0.92 & 0.66 & -0.41 \\
WindR & -0.45 & 0.31 & 0.98 & 0.47 & 0.29 & -0.23 \\
\hline
\end{tabular}

at the other 13 sites with higher precipitation of $\sim 1112 \mathrm{~mm} \mathrm{yr}^{-1}$ indicative of conditions where soil moisture is not limiting. Thus, the estimated $E$ minus $E_{\text {eq }}$ tend to have a higher $\mathrm{R}^{2}$ at site where $E$ is mainly controlled by precipitation and a lower $\mathrm{R}^{2}$ at site with $E$ likely controlled by available energy. Note that SGP site is water stressed due to its shallow soil. The slopes of the linear regression equation for estimated $E$ minus $E_{\text {eq }} v s$. observed $E$ minus $E_{\text {eq }}$ ranged from 0.09 at Donaldson to 0.98 at Tonzi, and the intercepts varied from $-0.56 \mathrm{~mm} \mathrm{~d}^{-1}$ at FermiA to $0.0 \mathrm{~mm} \mathrm{~d}^{-1}$ at Bartlett.

Scatterplots of daily average estimated $E$ minus $E_{\text {eq }}$ vs. observed $E$ minus $E_{\text {eq }}$ in Fig. 4 depict the strong correlation at sites of Tonzi, SGP, and Santa, and the weak correlation at sites of Donaldson, UMBS, and FermiP.

$\mathrm{R}^{2}$ and linear regression equation for estimated $E$ minus $E_{\mathrm{eq}}$ (Table 6) differ from that for estimated $E$ (Table 4 ) at 19 sites, which reveals that direct comparison of estimated $E$ with observed $E$ gives overconfidence in model performance only at site with $E$ mainly driven by available energy. However, Bias and RMSE of estimated $E$ minus $E_{\text {eq }} v s$. observed $E$ minus $E_{\text {eq }}$ almost equal to that of estimated $E v s$. observed E (Table 4).

ARTS $E$ model adopted a two factors $\left(R_{\mathrm{h}}\right.$ and $\left.L_{\mathrm{ai}}\right)$-based $G_{\mathrm{c}}$ model ignoring the impact of solar radiation $(S)$ and air temperature $\left(T_{a}\right)$. To evaluate the two factors-based $G_{\mathrm{c}}$ model, we developed a four factors $\left(S, T_{\mathrm{a}}, R_{\mathrm{h}}\right.$, and $\left.L_{\mathrm{ai}}\right)$-based $G_{\mathrm{c}}$ model,

$G_{\mathrm{c}}=g_{s \max } \times f(S) \times f\left(T_{a}\right) \times R_{\mathrm{h}} \times L_{\mathrm{ai}}$,

where $g_{\text {smax }}$ is $12.2 \mathrm{~m} \mathrm{~s}^{-1}$, the influence of $S$ and $T_{a}$ follows the definition of Stewart (1988) and Noilhan and Planton (1989), respectively,

$f(S)=(1+c / 1000) \times S /(c+S)$

$f\left(T_{a}\right)=1-0.0016\left(298-T_{a}\right)^{2}$

where $S$ is solar radiation $\left(\mathrm{W} \mathrm{m}^{-2}\right), c=100, T_{a}$ is air temperature $(\mathrm{k})$.

The new four factors-based $G_{\mathrm{c}}$ model was applied to calculate $E_{\mathrm{c}}$ (Eq. (6)) and was further compared with original $E_{\mathrm{c}}$ with the two factors-based $G_{c}$ model (Eq. (8)) at six sites (Fig. 5), which shows a strong correlation with $\mathrm{R}^{2}>0.98$ between two $E_{\mathrm{c}}$ driven with different $G_{\mathrm{c}}$ model, indicating that ignoring the direct impact of $S$ and $T_{a}$ on $G_{\mathrm{c}}$ dose not substantially change the variation in the calculated $E_{\mathrm{c}}$. This is consistent with many parameterizations of stomatal or surface conductance that neglect the direct effect of temperature (Landsberg \& Waring, 1997; Leuning et al., 2008; Stewart \& Gay, 1989) or solar radiation (Cleugh et al., 2007; Landsberg \& Waring, 1997; Mu et al., 2011) on canopy conductance.

\subsection{Analysis of global estimates of land evapotranspiration}

Global SRB radiation data and IGBP-DIS soil parameters were linearly interpolated to a spatial resolution of $0.5^{\circ}$. Global land $E$ from 1984 to 1998 was estimated using monthly remote sensing LAI, CRU climate, and SRB radiation data, at the same spatial resolution. Global spatial and temporal patterns of $E$ were analyzed. We estimated a mean annual land $E$ of $58.4 \times 10^{3} \mathrm{~km}^{3}$, which falls within the model range $\left(58 \times 10^{3}\right.$ $85 \times 10^{3} \mathrm{~km}^{3}$ ) estimated by the GSWP-2 project (Dirmeyer et al., 2006). But our global $E$ estimate is lower than the $62.8 \times 10^{3} \mathrm{~km}^{3}$ and $65.0 \times 10^{3} \mathrm{~km}^{3}$ reported by Mu et al. (2011) and Jung et al. (2010), respectively. This is partly because of a negative bias of net radiation in this study, which results from a negative bias of SRB SW radiation and a positive bias of SRB LW radiation (Gupta et al., 1992, 2001).

Fig. 6a shows the spatial distribution of annual $E$. Tropical and subtropical forests in South America, Africa, and Asia Island have a high $E$ of $1300 \mathrm{~mm} \mathrm{yr}^{-1}$. In contrast, the major deserts of North Africa, the Middle East, Middle Asia, and Australia, as well as high-latitude regions in the northern hemisphere, have an $E$ less than $200 \mathrm{~mm} \mathrm{yr}^{-1}$. 

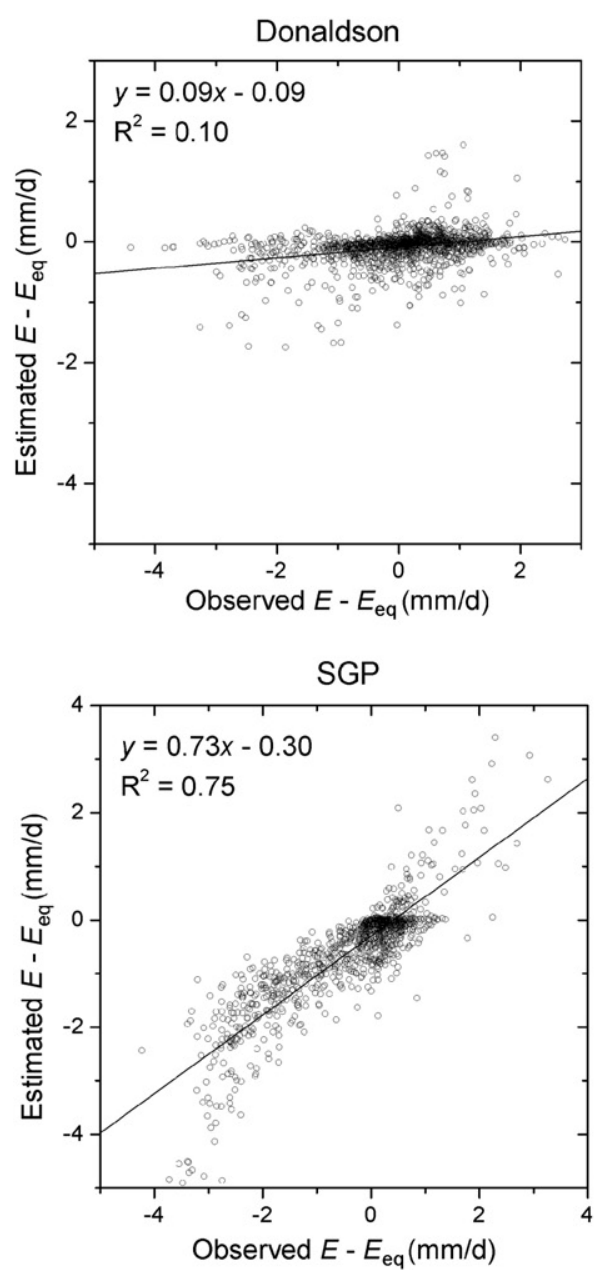
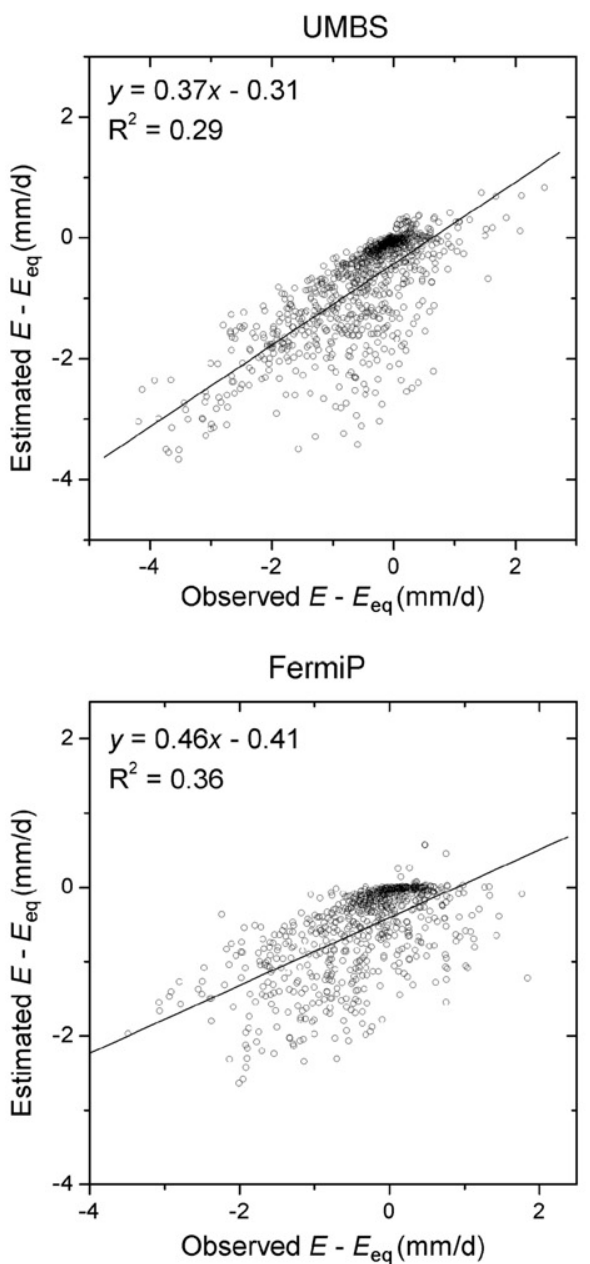
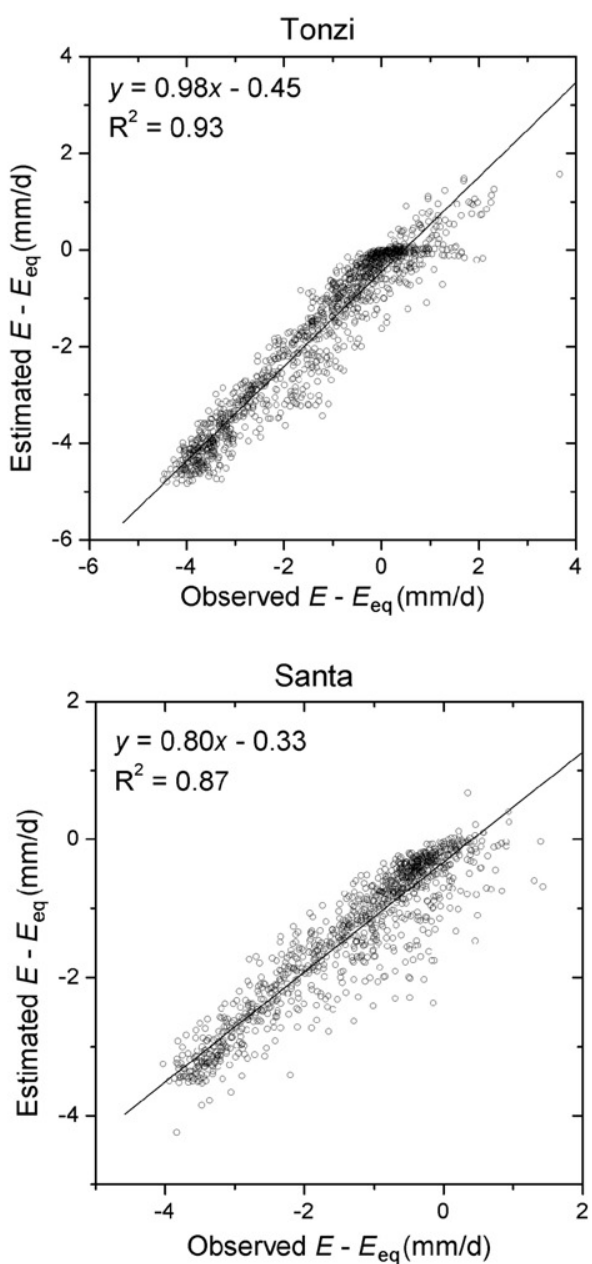

Fig. 4. Scatterplots of daily average estimated $E$ minus $E_{\mathrm{eq}} v s$. observed $E$ minus $E_{\mathrm{eq}}$ for the Donaldson, UMBS, Tonzi (top), SGP, FermiP, and Santa sites (bottom).

To assess the spatial pattern of $E$, we calculated the ratio of annual E to annual precipitation, averaged from 1984 to 1998 (Fig. 6b). This shows that in the major deserts of North Africa, Middle East, Middle Asia, and Australia, almost all precipitation evaporated into the atmosphere. In vegetated regions, annual $E$ is less than annual precipitation, i.e., precipitation is partly converted into $E$, with the residual going to runoff and leakage flow.

Fig. 7 shows the latitudinal mean of global land $E$, based on the ARTS $E$ model and the GSWP-2 project. The annual ARTS E, averaged over 1984-1998 (Fig. 7a), indicates that equatorial zones tend to have high annual $E$, over $1100 \mathrm{~mm} \mathrm{yr}^{-1}$. Mid- and high latitude zones often have low annual $E$, less than $450 \mathrm{~mm} \mathrm{yr}^{-1}$. Analogously, observed $E$ exceeded $920 \mathrm{~mm} \mathrm{yr}^{-1}$ at the two subtropical sites of Donaldson and Mize, whereas the $E$ at tundra and temperature sites ranged from $299 \mathrm{~mm} \mathrm{yr}^{-1}$ at Bartlett to $644 \mathrm{~mm} \mathrm{yr}^{-1}$ at MeadIR (Table 1). ARTS E values are within the range of observed $E$ at flux sites in this study.

Seasonally, the mid- and high latitude zones in the southern and northern hemispheres display a distinctive change. In January (Fig. 7b), E increases in the southern hemisphere (summer), and it decreases in the northern hemisphere (winter). In July (Fig. 7c), it is the reverse. The comparisons indicate that the ARTS model clearly captured the main features of annual $E$ (Fig. 7a) and seasonal $E$ (Figs. 7b and c) $v s$. latitude, in accord with the results of the GSWP-2 project. It also indicates that the obvious-hemispherical variation in $E$ is strongly driven by available energy.

Our global land $E$ estimates (Fig. 8) tend to increase from 1984 to 1998 , with a linear trend of $15.5 \mathrm{~mm}$ per decade $(P<0.01)$. This confirms the result of Jung et al. (2010) of global $E$ increase at a rate of
$9.9 \mathrm{~mm}$ per decade $(P<0.01)$ over the same period. This increase in $E$ is consistent with intensification of the land-based hydrologic cycle, because of combined surface solar brightening and increasing temperature (Jung et al., 2010; Wild et al., 2008). Jung et al. (2010) further asserted that the interannual variation of global $E$ correlates well with temperature variation during this period. However, contrary results (Zhang et al., 2011) were found that MTE and other satellite-based energy-balance methods might not explain trends in $E$ estimated using catchment water balances for wet regions due to use of remotely-sensed radiation and gridded meteorological fields with insufficient accuracy.

\section{Discussion}

The evaluation of ARTS $E$ at flux sites was affected by measurement error of flux $E$ data. The EC method has an energy imbalance problem, i.e., net radiation $R_{\mathrm{n}}$ minus ground heat flux $G$ is greater than the sum of latent heat flux $\lambda E$ and sensible heat flux $H$ at many eddy flux sites (Leuning et al., 2008; Wilson et al., 2002; Yan \& Shugart, 2010). The ratio of $\lambda E+H$ to $R_{\mathrm{n}}-G$ is about 0.8 for global FLUXNET measurements (Wilson et al., 2002). Thus, a correction method, i.e., energy closure ratios for EC measurements, has been proposed (Twine et al., 2000; Wilson et al., 2002) and applied to the calibration of empirical $E$ models (Jung et al., 2010; Nagler et al., 2005; Wang \& Liang, 2008). However, because physical $E$ models do not require calibration and the energy imbalance problem does not affect their development but degrades the error statistics of validation, these models often employ original flux $E$ 

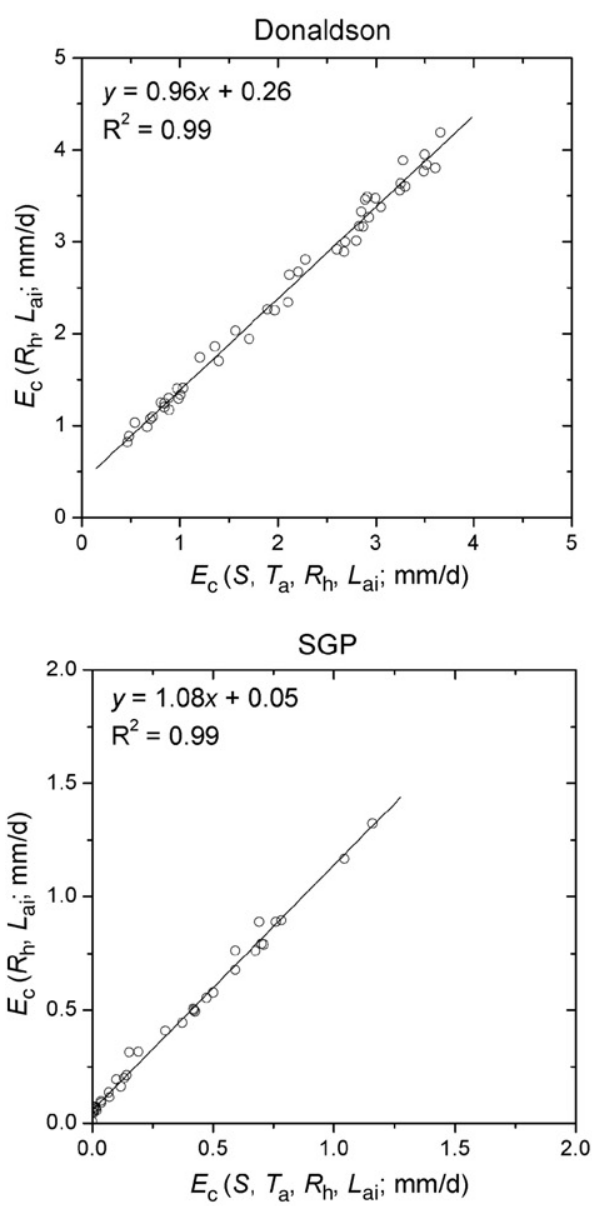

UMBS
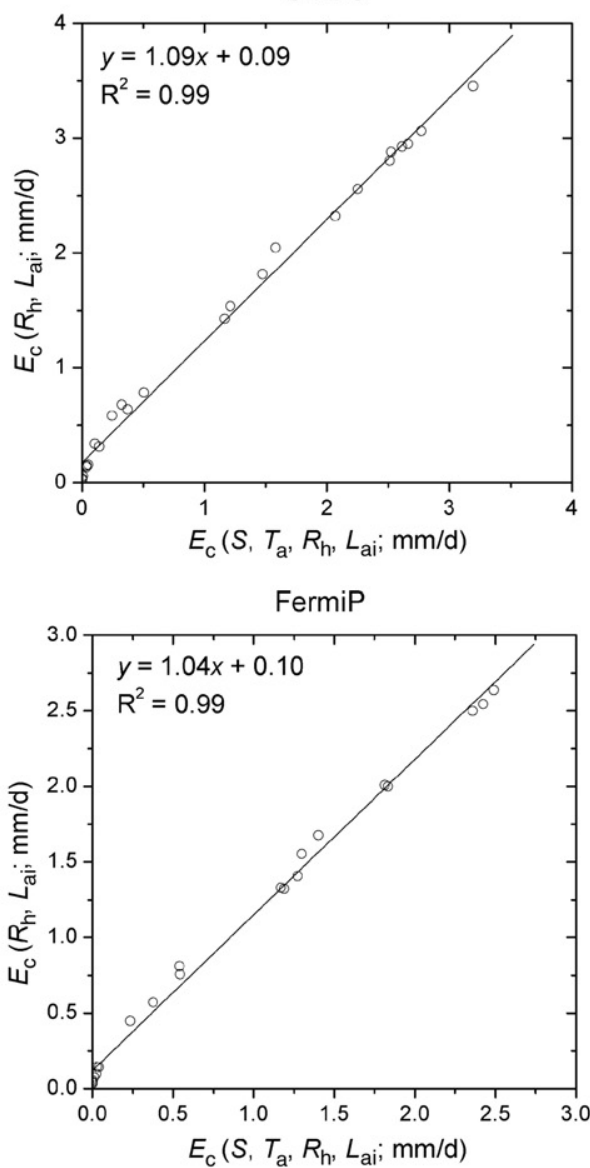
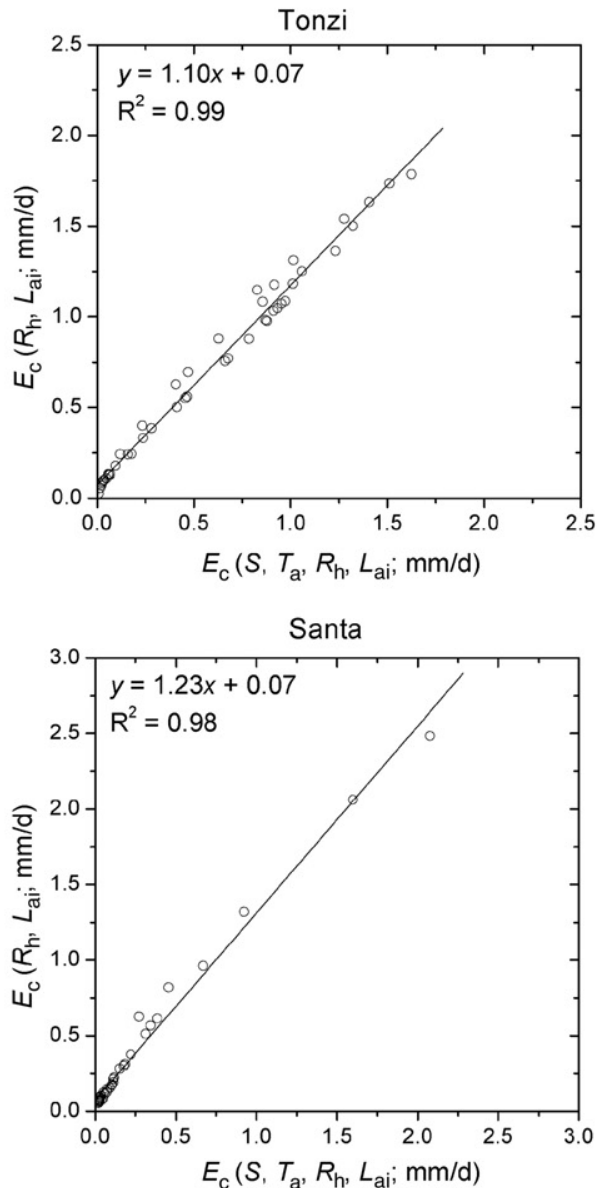

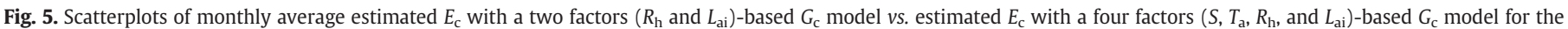
Donaldson, UMBS, Tonzi (top), SGP, FermiP, and Santa sites (bottom).

for validation, without regard to the energy imbalance problem (current study; Fisher et al., 2008; Mu et al., 2007, 2011).

Although it is common to use continuous daily precipitation, air temperature, and $E_{0}$ in the SWB model to simulate daily $E$, there are missing observation data at most flux sites (Neal et al., 2011; current study). The discontinuous daily data had to be applied to the SWB model here, which inevitably causes uncertainties in daily $E$ estimates. Fortunately, data gaps typical of EC records typically last a week or less (Neal et al., 2011), and it is our assessment that such short-term data gaps do not significantly affect our modeling results and main conclusions, drawn from daily evaluation. For monthly data, gap-filling was done to create continuous monthly data (Moffat et al., 2007; Papale \& Valentini, 2003; Reichstein et al., 2005), and hence ARTS E was properly estimated at the monthly scale.

Remote sensing-retrieved $L_{\mathrm{ai}}$ is a key input variable to calculate $G_{\mathrm{c}}$ because substantial vegetation often corresponds to higher $E_{\mathrm{c}}$ and $E$. Further, variation of vegetation detected by remote sensing has been found to have a close relationship with interannual $E$ variation (Suzuki et al., 2007). Despite inevitable impacts on the quality of retrieved $L_{\mathrm{ai}}$ by the $L_{\mathrm{ai}}$ algorithm, remote sensing calibration, and cloud and smoke contamination (Myneni et al., 2002), remotely sensed $L_{\mathrm{ai}}$ has been used in canopy conductance modeling for large spatial applications or climate simulations (Buermann et al., 2001). We believe that improvement of $L_{\mathrm{ai}}$ retrieval by the remote sensing research group will enhance the accuracy of $E$ estimation, on a wide range of temporal and spatial scales.

Uncertainties in other input forcings of climate and radiation data also contribute to uncertainties in ARTS E. Negative bias, against ground measurements, in net radiation $R_{\mathrm{n}}$ derived from SRB radiation (Gupta et al., 2001) produced lower estimates of global $E$ in this study than that of Mu et al. (2011) and Jung et al. (2010). Further, Zhang et al. (2011) conclude that the SRB radiation estimates are likely in error by comparing regional trends in $E$ estimated using MTE and a PM model (Leuning et al., 2008) driven by SRB available energy with those estimated using catchment water balances. CRU 3.0 climate data often had interpolation error, which is inevitable and varies with climate elements and location. The precipitation data have a systematic gauge measurement error, i.e., an underestimation of the true precipitation. This varies between $5 \%$ and over $100 \%$ vs. measured data for monthly accumulated precipitation, depending on weather conditions (New et al., 1999). However, CRU climate and SRB radiation data, as an available dataset, have been widely used in global $E$ estimates (Fisher et al., 2008; Sheffield et al., 2010; Zhang et al., 2011). To assess uncertainties from input datasets, further intercomparison of global $E$ estimates, using other global reanalysis data, will be the subject of future work.

More physical processes considered will improve the ARTS E model. For instance, many ground measurements have shown that there are considerable day-to-day variations and seasonality in $G$ across a wide range of geography (Halliwell \& Rouse, 1987; Heitman et al., 2010; Kakane, 2004; Meulen \& Klaassen, 1996). Thus ignoring $G$ in calculation of $A$ as a simple simplification for practical application might result in potential uncertainty in $E$ calculation, which will be considered in future work.

The ARTS model incorporates $R_{\mathrm{h}}$ in the canopy conductance model, whereas previous $E$ models frequently use $D$ in this model (Mu et al., 2007, 2011; Leuning et al., 2008). One inconvenience of using $D$ is that it must be normalized, using a constant dependent on vegetation type (Mu et al., 2011). Clearly, $R_{\mathrm{h}}$ as a normalized value reduces the complexity of the $E$ model. 
(a) Annual E (1984-1998)

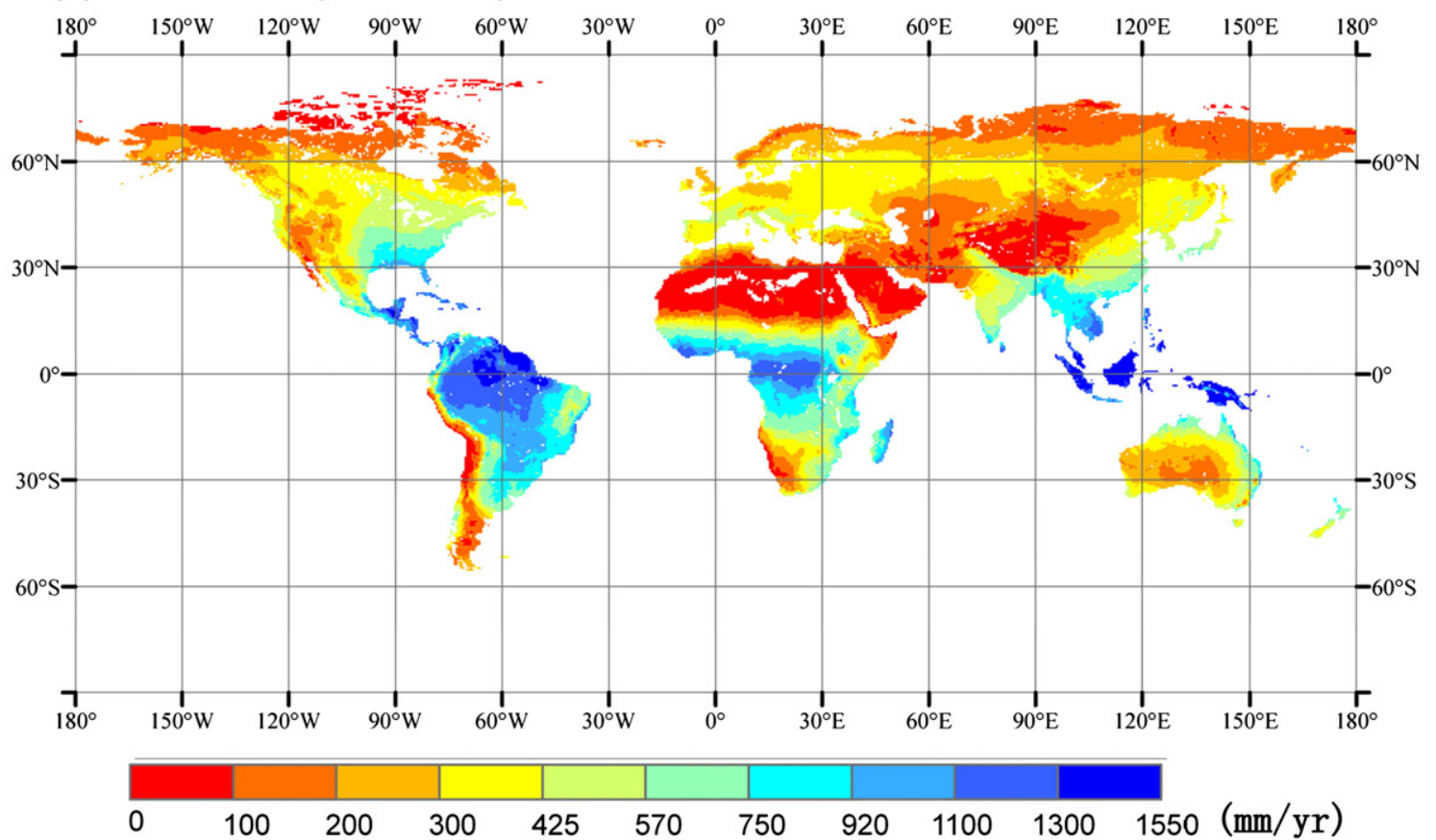

(b) Ratio of annual $E$ to annual precipitation (1984-1998)

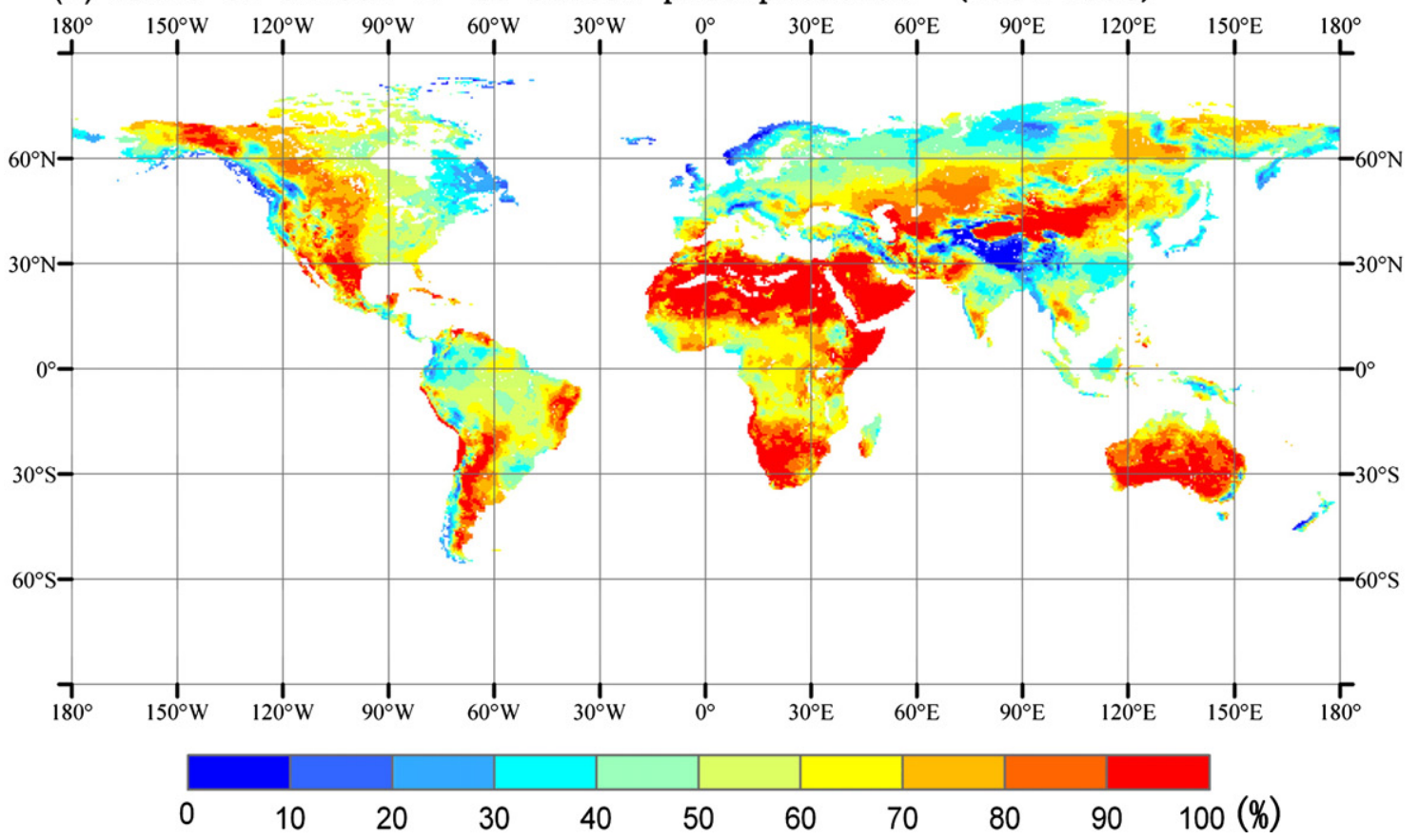

Fig. 6. Global annual $E$ (a) and ratio (b) of annual $E$ to annual precipitation averaged from 1984 to 1998.

Fundamentally, $E$ is controlled by atmospheric demand and terrestrial water supply. $E$ is restricted by soil water deficit for a waterstressed surface, where precipitation is the upper limit of $E$ if irrigation and lateral flows are ignored. Thus, to accurately estimate $E$, the soil water constraint has to be considered. Some methods have been developed to simulate or substitute for it, however, because of scarce soil moisture observation. Wang and Liang (2008) proposed the diurnal land surface temperature range to address the influence of soil moisture on $E$. Fisher et al. (2008) recently proposed an index of soil water deficit, defined as $R_{\mathrm{h}}^{D}$, based on the complementary hypothesis of Bouchet (1963), which suits sufficiently large spatial and temporal scales when the atmosphere is in equilibrium with underlying soil. However, there are obviously exceptional cases confronting the application of $R_{\mathrm{h}}^{D}$, owing to advection when humid air passes over dry soil (Fisher et al., 2008). In other words, $R_{\mathrm{h}}^{D}$ may not explicitly represent the soil water deficit on daily scales when such advection is frequent, or in dry regions where precipitation controls $E$ processes. Wang et al. (2007) argued that any $E$ parameterization without consideration of soil moisture content will overestimate $E$ during drought conditions. Since the SWB model has no such problems and its capacity to simulate soil water deficit with precipitation input at variable temporal scales, SWB model is suggested to account for soil water deficit in the $E$ estimation algorithm. 
(a) Annual E

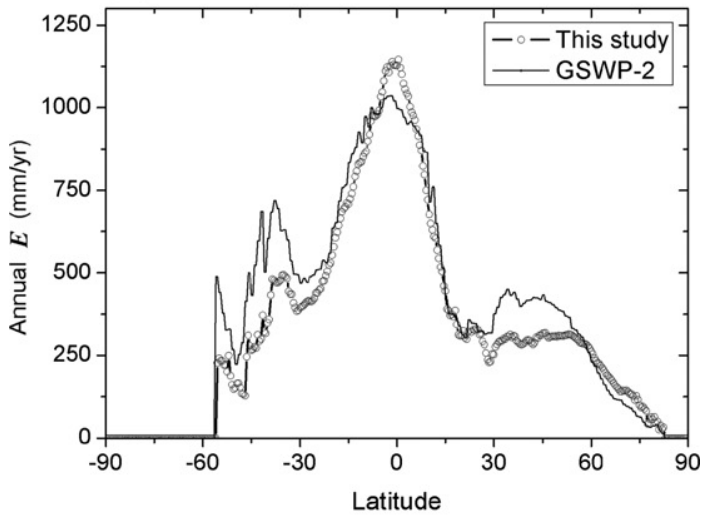

(b) $E$ in January

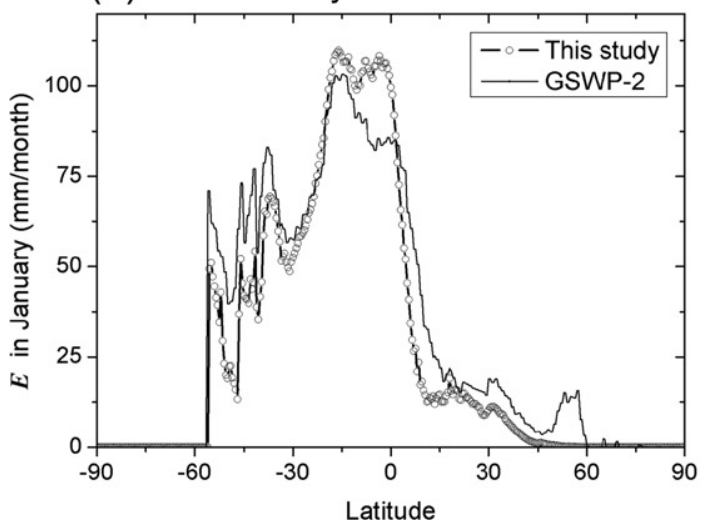

(c) $E$ in July

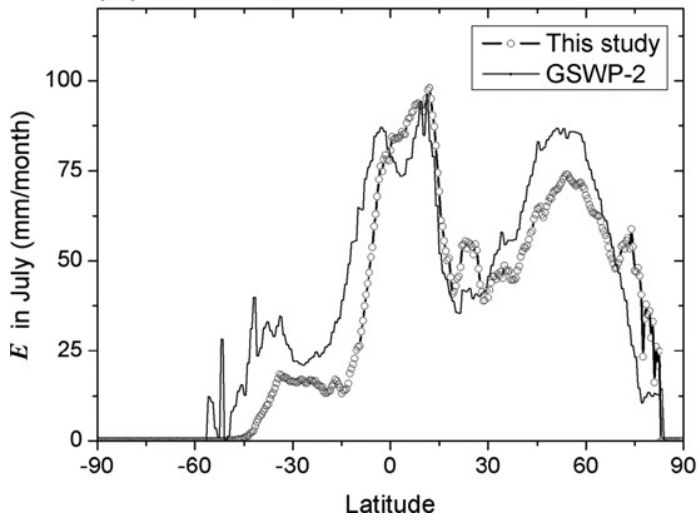

Fig. 7. Comparison of the latitudinal mean $\left(-90^{\circ} \mathrm{S}\right.$ to $\left.90^{\circ} \mathrm{N}\right)$ of (a) annual, (b) January, and (c) July global land $E$ based on ARTS model and GSWP-2 model.

\section{Conclusions}

The ARTS E model uses remote sensing observations to predict the rates of $E$ globally. It accounts for the impact of net radiation, air temperature, air moisture deficit, soil water deficit, and vegetation LAI, thereby adequately representing the principles of surface energy balance and water balance. The ARTS $E$ model shows good agreement with observed $E$ at 19 flux sites, at daily and monthly scales. The evaluation also indicates that the PM equation provides a practical framework with which to incorporate a canopy conductance model in the plant transpiration model and that the SWB model is capable of representing the effect of soil water deficit on plant transpiration and soil evaporation.

The further evaluation of ARTS $E$ model, by using residuals of subtracting $E_{\mathrm{eq}}$ from the estimated and measured $E$, reveals that ARTS $E$ model has better performance with regards to accounting for the residuals at sites where $E$ is controlled by precipitation than that at sites

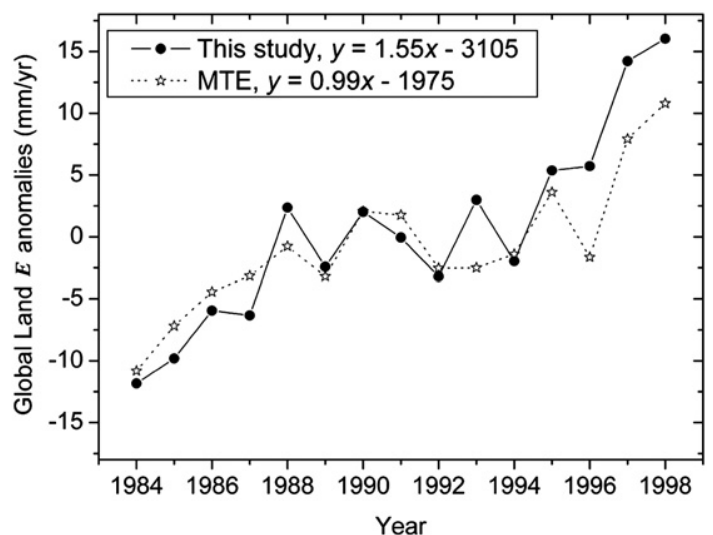

Fig. 8. Annual global land $E$ anomalies based on ARTS model in this study and MTE model from 1984 to 1998.

with $E$ controlled by available energy. We hypothesize that this is because $E_{\text {eq }}$ comprised the major contribution of available energy in these sites. This type of evaluation is a supplement to routine evaluation method, e.g., directly comparing estimated $E$ with observed $E$, which often result with over-confidence in model performance at site where much of the variation in $E$ is driven by the corresponding variation in available energy.

As a physical $E$ model with no need of calibration, ARTS has the potential for implementation at variable temporal and spatial scales. The input data for the proposed ARTS E model include meteorological, $L_{\mathrm{ai}}$, and soil data, most of which are readily available. The regional or global $E$ estimates will be of great interest in terrestrial water cycle and climate change research.

\section{Acknowledgments}

The authors would like to thank the flux site investigators for allowing us to use their flux data through AmeriFlux program for the development of ARTS E model. This work was supported by National Natural Science Foundation of China (41171284, 40801129), Special Fund for Meteorological Research in the Public Interest (GYHY201106027, 200906022) and Chinese Academy of Sciences (XDA05050602-1). Flux observations at UMBS were supported by US DoE grant \# DESC0006708. Finally the reviewers and Dr. Junchang Ju are thanked for the constructive remarks and suggestions.

\section{References}

Alkama, R., Decharme, B., Douville, H., \& Ribes, A. (2011). Trends in global and basin-scale runoff over the late twentieth century: Methodological issues and sources of uncertainty. Journal of Climate, 24, 3000-3014.

Allen, R. G. (1998). Crop evapotranspiration: Guidelines for computing crop water requirements. Rome: Food and Agriculture Organization of the United Nations.

Anderson, M. C., Norman, J. M., Mecikalski, J. R., Otkin, J. A., \& Kustas, W. P. (2007). A climatological study of evapotranspiration and moisture stress across the continental United States based on thermal remote sensing: 1. Model formulation. Journal of Geophysical Research-Atmospheres, 112, D10117.

Baldocchi, D., Falge, E., Gu, L. H., Olson, R., Hollinger, D., Running, S., et al. (2001). FLUXNET: A new tool to study the temporal and spatial variability of ecosystem-scale carbon dioxide, water vapor, and energy flux densities. Bulletin of the American Meteorological Society, 82, 2415-2434.

Ball, J., Woodrow, L. E., \& Beny, J. A. (1987). A model predicting stomatal conductance and its contribution to the control of photosynthesis under different environmental conditions. In J. Biggins (Ed.), Progress in Photosynthesis research (pp. 221-224). Dordrecht: Nijhoff.

Bastiaanssen, W. G. M., Pelgrum, H., Wang, J., Ma, Y., Moreno, J. F., Roerink, G. J., et al. (1998). A remote sensing surface energy balance algorithm for land (SEBAL). (Part 2: Validation). Journal of Hydrology, 212-213 (213-229).

Batra, N., Islam, S., Venturini, V., Bisht, G., \& Jiang L. (2006). Estimation and comparison of evapotranspiration from MODIS and AVHRR sensors for clear sky days over the Southern Great Plains. Remote Sensing of Environment, 103, 1-15.

Bonan, G. B. (1996). A land surface model (LSM version 1.0) for ecological, hydrological, and atmospheric studies: technical description and user's guide. NCAR Technical Note 
NCAR/TN-417+STR (pp. 150). Boulder, Colorado: National Center for Atmospheric Research.

Bouchet, R. J. (1963). Evapotranspiration reelle et potentielle, signification climatique. International Association of Science and Hydrology, 62, 134-142.

Buermann, W., Dong, J., Zeng, X., Myneni, R. B., \& Dickinson, R. E. (2001). Evaluation of the utility of satellite-based vegetation leaf area index data for climate simulations. Journal of Climate, 14, 3536-3550.

Chen, J. Q., Davis, K. J., \& Meyers, T. P. (2008). Ecosystem-atmosphere carbon and water cycling in the upper Great Lakes Region. Agricultural and Forest Meteorology, 148, 155-157.

Chen, D., Gao, G., Xu, C. -Y., Guo, J., \& Ren, G. (2005). Comparison of the Thornthwaite method and pan data with the standard Penman-Monteith estimates of reference evapotranspiration in China. Climate Research, 28, 123-132.

Chen, J. M., Liu, J., Cihlar, J., \& Goulden, M. L. (1999). Daily canopy photosynthesis model through temporal and spatial scaling for remote sensing applications. Ecological Modelling, 124, 99-119.

Clark, K. L., Gholz, H. L., \& Castro, M. S. (2004). Carbon dynamics along a chronosequence of slash pine plantations in north Florida. Ecological Applications, 14, 1154-1171.

Cleugh, H. A., Leuning, R., Mu, Q., \& Running, S. W. (2007). Regional evaporation estimates from flux tower and MODIS satellite data. Remote Sensing of Environment, 106, 285-304.

Collatz, G. J., Ball, J. T., Grivet, C., \& Berry, J. A. (1991). Physiological and environmental regulation of stomatal conductance, photosynthesis and transpiration: A model that includes a laminar boundary layer. Agricultural and Forest Meteorology, 54, 107-136.

Dai, Y., Dickinson, R. E., \& Wang, Y. -P. (2004). A two-big-leaf model for canopy temperature, photosynthesis, and stomatal conductance. Journal of Climate, 17, 2281-2299.

Dang, Q. L., Margolis, H. A., Coyea, M. R., Sy, M., \& Collatz, G. J. (1997). Regulation of branch-level gas exchange of boreal trees: Roles of shoot water potential and vapor pressure difference. Tree Physiology, 17, 521-535.

Desai, A. R., Noormets, A., Bolstad, P. V., Chen, J. Q., Cook, B. D., Davis, K. J., et al. (2008). Influence of vegetation and seasonal forcing on carbon dioxide fluxes across the Upper Midwest, USA: Implications for regional scaling. Agricultural and Forest Meteorology, 148, 288-308.

Dirmeyer, P. A., Gao, X., Zhao, M., Guo, Z., Oki, T., \& Hanasaki, N. (2006). GSWP-2: Multimodel analysis and implications for our perception of the land surface. Bulletin of the American Meteorological Society, 87, 1381-1397.

Dragoni, D., Schmid, H. P., Grimmond, C. S. B., \& Loescher, H. W. (2007). Uncertainty of annual net ecosystem productivity estimated using eddy covariance flux measurements. Journal of Geophysical Research-Atmospheres, 112, D17102 (17110.11029/ 12006jd008149)

Falk, M., Wharton, S., Schroeder, M., Ustin, S., \& U.K.T.P. (2008). Flux partitioning in an old-growth forest: Seasonal and interannual dynamics. Tree Physiology, 28, 509-520.

Fisher, J. B., Tu, K. P., \& Baldocchi, D. D. (2008). Global estimates of the land-atmosphere water flux based on monthly AVHRR and ISLSCP-II data, validated at 16 FLUXNET sites. Remote Sensing of Environment, 112, 901-919.

Grant, R. F., Arkebauer, T. J., Dobermann, A., Hubbard, K. G., Schimelfenig, T. T., Suyker, A. E., et al. (2007). Net biome productivity of irrigated and rainfed maize-soybean rotations: Modeling vs. measurements. Agronomy Journal, 99, 1404-1423.

Gupta, S. K., Darnell, W. L., \& Wilber, A. C. (1992). A parameterization for longwave surface radiation from satellite data: Recent improvements. Journal of Applied Meteorology, 31, 1361-1367.

Gupta, S. K., Kratz, D. P., Stackhouse, P. W., Jr., \& Wilber, A. C. (2001). The Langley Parameterized Shortwave Algorithm (LPSA) for Surface Radiation Budget Studies. NASA/TP-2001-211272. [31 pp.].

Hall, F. G., Brown de Colstoun, E., Collatz, G. J., Landis, D., Dirmeyer, P., Betts, A., et al. (2006). ISLSCP Initiative II global data sets: Surface boundary conditions and atmospheric forcings for land-atmosphere studies. Journal of Geophysical Research-Atmospheres, 111, D22S01.

Halliwell, D. H., \& Rouse, W. R. (1987). Soil heat flux in permafrost: Characteristics and accuracy of measurement. Journal of Climatology, 7, 571-584.

Harazono, Y., Mano, M., Miyata, A., Zulueta, R. C., \& Oechel, W. C. (2003). Inter-annual carbon dioxide uptake of a wet sedge tundra ecosystem in the Arctic. Tellus Series B: Chemical and Physical Meteorology, 55, 215-231.

Heitman, J. L., Horton, R., Sauer, T. J., Ren, T. S., \& Xiao, X. (2010). Latent heat in soil heat flux measurements. Agricultural and Forest Meteorology, 150, 1147-1153.

Huntington, T. G. (2006). Evidence for intensification of the global water cycle: Review and synthesis. Journal of Hydrology, 319, 83-95.

Impens, I., \& Lemeur, R. (1969). Extinction of net radiation in different crop canopies. Theoretical and Applied Climatology, 17, 403-412.

Irvine, J., Law, B. E., \& Hibbard, K. A. (2007). Postfire carbon pools and fluxes in semiarid ponderosa pine in Central Oregon. Global Change Biology, 13, 1748-1760.

Jarvis, P. G. (1976). Interpretation of variations in leaf water potential and stomatal conductance found in canopies in field. Philosophical Transactions of the Royal Society of London. Series B, Biological Sciences, 273, 593-610.

Jung, M., Reichstein, M., Ciais, P., Seneviratne, S. I., Sheffield, J., Goulden, M. L., et al. (2010). Recent decline in the global land evapotranspiration trend due to limited moisture supply. Nature, 467, 951-954.

Kakane, V. (2004). Soil heat flux-net radiation relations for some surfaces. West African Journal of Applied Ecology, 5, 21-29.

Kelliher, F. M., Leuning, R., Raupach, M. R., \& Schulze, E. D. (1995). Maximum conductances for evaporation from global vegetation types. Agricultural and Forest Meteorology, 73, 1-16.

Kistler, R., Kalnay, E., Collins, W., Saha, S., White, G., Woollen, J., et al. (2001). The NCEPNCAR 50-year reanalysis: Monthly means CD-ROM and documentation. Bulletin of the American Meteorological Society, 82, 247-267.
Körner, C. H. (1994). Leaf diffusive conductances in the major vegetation types of the globe. In E. D. Schulze, \& M. M. Caldwell (Eds.), Ecophysiology of photosynthesis. Ecol Studies, 100. (pp. 463-490) Berlin, Heidelberg, New York: Springer.

Kustas, W. P., \& Norman, J. M. (1999). Evaluation of soil and vegetation heat flux predictions using a simple two-source model with radiometric temperatures for partial canopy cover. Agricultural and Forest Meteorology, 94, 13-29.

Labat, D., Goddéris, Y., Probst, J. L., \& Guyot, J. L. (2004). Evidence for global runoff increase related to climate warming. Advances in Water Resources, 27, 631-642.

Landsberg, J. J., \& Waring, R. H. (1997). A generalised model of forest productivity using simplified concepts of radiation-use efficiency, carbon balance and partitioning. Forest Ecology and Management, 95, 209-228.

Leuning, R. (1995). A critical-appraisal of a combined stomatal-photosynthesis model for C-3 plants. Plant, Cell \& Environment, 18, 339-355.

Leuning, R., Zhang, Y. Q., Rajaud, A., Cleugh, H., \& Tu, K. (2008). A simple surface conductance model to estimate regional evaporation using MODIS leaf area index and the Penman-Monteith equation. Water Resources Research, 44, W10419.

Los, S. O., Pollack, N. H., Parris, M. T., Collatz, G. J., Tucker, C. J., Sellers, P. J., et al. (2000). A global 9-yr biophysical land surface dataset from NOAA AVHRR data. Journal of Hydrometeorology, 1, 183-199.

Ma, S. Y., Baldocchi, D. D., Xu, L. K., \& Hehn, T. (2007). Inter-annual variability in carbon dioxide exchange of an oak/grass savanna and open grassland in California. Agricultural and Forest Meteorology, 147, 157-171.

Malmström, C. M., Thompson, M. V., Juday, G. P., Los, S. O., Randerson, J. T., \& Field, C. B. (1997). Interannual variation in global-scale net primary production: Testing model estimates. Global Biogeochemical Cycles, 11, 367-392.

Meulen, M. W. J., \& Klaassen, W. (1996). Soil heat flux measurements in an open forest. Physics and Chemistry of the Earth, 21, 101-105.

Moffat, A. M., Papale, D., Reichstein, M., Hollinger, D. Y., Richardson, A. D., Barr, A. G., et al. (2007). Comprehensive comparison of gap-filling techniques for eddy covariance net carbon fluxes. Agricultural and Forest Meteorology, 147, 209-232.

Monteith, J. L. (1965). Evaporation and the environment. Symposia of the Society for Experiment Biology, 19, 205-234.

Monteith, J.L., \& Unsworth, M.H. (1990). Principles of environmental physics. (2nd ed.) London; New York: E. Arnold; Distributed in the USA by Routledge, Chapman and Hall.

Moran, M. S., Clarke, T. R., Kustas, W. P., Weltz, M., \& Amer, S. A. (1994). Evaluation of hydrologic parameters in a semiarid rangeland using remotely sensed spectral data. Water Resources Research, 30, 1287-1297.

Mu, Q., Heinsch, F. A., Zhao, M., \& Running, S. W. (2007). Development of a global evapotranspiration algorithm based on MODIS and global meteorology data. Remote Sensing of Environment, 111, 519-536.

Mu, Q., Zhao, M., \& Running, S. W. (2011). Improvements to a MODIS global terrestrial evapotranspiration algorithm. Remote Sensing of Environment, 115, 1781-1800.

Myneni, R. B., Hoffman, S., Knyazikhin, Y., Privette, J. L., Glassy, J., Tian, Y., et al. (2002). Global products of vegetation leaf area and fraction absorbed PAR from year one of MODIS data. Remote Sensing of Environment, 83, 214-231.

Nagler, P. L., Cleverly, J., Glenn, E., Lampkin, D., Huete, A., \& Wan, Z. (2005). Predicting riparian evapotranspiration from MODIS vegetation indices and meteorological data. Remote Sensing of Environment, 94, 17-30.

Nave, L. E., Gough, C. M., Maurer, K. D., Bohrer, G., Hardiman, B., Le Moine, J., et al. (2011) Disturbance and the resilience of coupled carbon and nitrogen cycling in a north temperate forest. Journal of Geophysical Research-Biogeosciences, 116, G04016.

Neal, A. L., Gupta, H. V., Kurc, S. A., \& Brooks, P. D. (2011). Modeling moisture fluxes using artificial neural networks: Can information extraction overcome data loss? Hydrology and Earth System Sciences, 15, 359-368.

Nemani, R. R., \& Running, S. W. (1989). Estimation of regional surface resistance to evapotranspiration from NDVI and thermal-IR AVHRR data. Journal of Applied Meteorology, 28, 276-284.

New, M., Hulme, M., \& Jones, P. D. (1999). Representing twentieth century space-time climate variability. Part 1: development of a 1961-90 mean monthly terrestrial climatology. Journal of Climate, 12, 829-856.

New, M., Hulme, M., \& Jones, P. (2000). Representing twentieth-century space-time climate variability. Part II: development of 1901-96 monthly grids of terrestrial surface climate. Journal of Climate, 13, 2217-2238.

Nishida, K., Nemani, R. R., Running, S. W., \& Glassy, J. M. (2003). An operational remote sensing algorithm of land surface evaporation. Journal of Geophysical Research-Atmospheres, 108, 4270

Niyogi, D. S., \& Raman, S. (1997). Comparison of four different stomatal resistance schemes using FIFE observations. Journal of Applied Meteorology, 36, 903-917.

Noilhan, J., \& Planton, S. (1989). A simple parameterization of land surface processes for meteorological models. Monthly Weather Review, 117, 536-549.

Norman, J. M., Kustas, W. P., \& Humes, K. S. (1995). Source approach for estimating soil and vegetation energy fluxes in observations of directional radiometric surface temperature. Agricultural and Forest Meteorology, 77, 263-293.

Oki, T., \& Kanae, S. (2006). Global hydrological cycles and world water resources. Science, 313, 1068-1072.

Papale, D., \& Valentini, R. (2003). A new assessment of European forests carbon exchanges by eddy fluxes and artificial neural network spatialization. Global Change Biology, 9, 525-535.

Paw, U. K. T., Baldocchi, D. D., Meyers, T. P., \& Wilson, K. B. (2000). Correction of eddycovariance measurements incorporating both advective effects and density fluxes. Boundary-Layer Meteorology, 97, 487-511.

Priestley, C. H., \& Taylor, R. J. (1972). Assessment of surface heat-flux and evaporation using large-scale parameters. Monthly Weather Review, 100, 81-92.

Reichstein, M., Falge, E., Baldocchi, D., Papale, D., Aubinet, M., Berbigier, P., et al. (2005) On the separation of net ecosystem exchange into assimilation and ecosystem respiration: Review and improved algorithm. Global Change Biology, 11, 1424-1439. 
Ryu, Y., Baldocchi, D. D., Ma, S., \& Hehn, T. (2008). Interannual variability of evapotranspiration and energy exchange over an annual grassland in California. Journal of Geophysical Research-Atmospheres, 113, D09104 (09110.01029/02007jd009263).

Ryu, Y., Baldocchi, D., Black, T. A., Detto, M., Law, B. E., Leuning, R., et al. (2012). On the temporal upscaling of evapotranspiration from instantaneous remote sensing measurements to 8-day mean daily-sums. Agricultural and Forest Meteorology, $152,212-222$.

Saugier, B., \& Katerji, N. (1991). Some plant factors controlling evapotranspiration. Agricultural and Forest Meteorology, 54, 263-277.

Saxton, K. E., Rawls, W. J., Romberger, J. S., \& Papendick, R. I. (1986). Estimating generalized soil-water characteristics from texture. Soil Science Society of America Journal, 50, 1031-1036.

Scott, R. L., Jenerette, G. D., Potts, D. L., \& Huxman, T. E. (2009). Effects of seasonal drought on net carbon dioxide exchange from a woody-plant-encroached semiarid grassland. Journal of Geophysical Research-Atmospheres, 114, G04004.

Sellers, P. J., Randall, D. A., Collatz, G. J., Berry, J. A., Field, C. B., Dazlich, D. A., et al. (1996). A revised land surface parameterization (SiB2) for atmospheric GCMS. Part I: Model formulation. Journal of Climate, 9, 676-705.

Sellers, P. J., Shuttleworth, W. J., Dorman, J. L., Dalcher, A., \& Roberts, J. M. (1989). Calibrating the simple biosphere model for Amazonian tropical forest using field and remote sensing data. Part I: Average calibration with field data. Journal of Applied Meteorology, 28, 727-759.

Sheffield, J., Wood, E. F., \& Munoz-Arriola, F. (2010). Long-term regional estimates of evapotranspiration for Mexico based on downscaled ISCCP data. Journal of Hydrometeorology, 11, 253-275.

Sheridan, P. J., Delene, D. J., \& Ogren, J. A. (2001). Four years of continuous surface aerosol measurements from the Department of Energy's Atmospheric Radiation Measurement Program Southern Great Plains Cloud and Radiation Testbed site. Journal of Geophysical Research-Atmospheres, 106, 20735-20747.

Shugart, H. H. (1998). Terrestrial ecosystems in changing environments. Cambridge; New York: Cambridge University Press.

Shuttleworth, W. J., \& Wallace, J. S. (1985). Evaporation from sparse crops-An energy combination theory. Quarterly Journal of the Royal Meteorological Society, 111, 839-855.

Stewart, J. B. (1988). Modelling surface conductance of pine forest. Agricultural and Forest Meteorology, 43, 19-35.

Stewart, J. B., \& Gay, L. W. (1989). Preliminary modelling of transpiration from the FIFE site in Kansas. Agricultural and Forest Meteorology, 48, 305-315.

Su, Z. (2002). The Surface Energy Balance System (SEBS) for estimation of turbulent heat fluxes. Hydrology and Earth System Sciences, 6, 85-100.

Suyker, A. E., \& Verma, S. B. (2008). Interannual water vapor and energy exchange in an irrigated maize-based agroecosystem. Agricultural and Forest Meteorology, 148, 417-427.

Suzuki, R. Masuda, K., Dye, G. \& D. (2007). Interannual covariability between actua evapotranspiration and PAL and GIMMS NDVIs of northern Asia. Remote Sensing of Environment, 106, 387-398.

Thomas, C. K., Law, B. E., Irvine, J., Martin, J. G., Pettijohn, J. C., \& Davis, K. J. (2009). Seasonal hydrology explains interannual and seasonal variation in carbon and water exchange in a semiarid mature ponderosa pine forest in central Oregon. Journal of Geophysical Research-Atmospheres, 114, G04006.

Thornthwaite, C. W., \& Mather, J. R. (1955). The water balance. In, Publications in climatology. New Jersey: Drexel Institute of Technology.

Trenberth, K. E., Fasullo, J. T., \& Kiehl, J. (2009). Earth's Global Energy Budget. Bulletin of the American Meteorological Society, 90, 311-323.
Twine, T. E Kustas, W. P. Norman, J. M. Cook, D. R, Houser, P. R, Meyers, T. P., et al. (2000). Correcting eddy-covariance flux underestimates over a grassland. Agricultural and Forest Meteorology, 103, 279-300.

Vinukollu, R. K., Wood, E. F., Ferguson, C. R., \& Fisher, J. B. (2011). Global estimates of evapotranspiration for climate studies using multi-sensor remote sensing data: Evaluation of three process-based approaches. Remote Sensing of Environment, $115,801-823$.

Wang, K. C., \& Liang, S. L. (2008). An improved method for estimating global evapotranspiration based on satellite determination of surface net radiation, vegetation index, temperature, and soil moisture. Journal of Hydrometeorology, 9, 712-727.

Wang, K., Wang, P., Li, Z., Sparrow, M., \& Cribb, M. (2007). A simple method to estimate evapotranspiration from a combination of net radiation, vegetation indices and temperatures. Journal of Geophysical Research, 112, D15107. http://dx.doi.org/10.1029/2006JD008351.

Wang, S. S., Yang, Y., Trishchenko, A. P., Barr, A. G., Black, T. A., \& McCaughey, H. (2009). Modeling the response of canopy stomatal conductance to humidity. Journal of Hydrometeorology, 10, 521-532.

Wild, M., Grieser, J., \& Schär, C. (2008). Combined surface solar brightening and increasing greenhouse effect support recent intensification of the global land-based hydrological cycle. Geophysical Research Letters, 35, L17706.

Wilson, K., Goldstein, A., Falge, E., Aubinet, M., Baldocchi, D., Berbigier, P., et al. (2002). Energy balance closure at FLUXNET sites. Agricultural and Forest Meteorology, 113, 223-243.

Xiao, J., Zhuang, Q., Baldocchi, D. D., Law, B. E., Richardson, A. D., Chen, J., et al. (2008). Estimation of net ecosystem carbon exchange for the conterminous United States by combining MODIS and AmeriFlux data. Agricultural and Forest Meteorology, 148, 1827-1847.

Yan, H., \& Shugart, H. H. (2010). An air relative-humidity-based evapotranspiration model from eddy covariance data. Journal of Geophysical Research-Atmospheres, 115, D16106.

Yu, G. R., Nakayama, K., \& Lu, H. Q. (1996). Modelling stomatal conductance in maize leaves with environmental variable (in Japanese with English summary). Journal of Agricultural Meteorology, 52, 324-330.

Yuan, W., Liu, S., Yu, G., Bonnefond, J. M., Chen, J., Davis, K., et al. (2010). Global estimates of evapotranspiration and gross primary production based on MODIS and global meteorology data. Remote Sensing of Environment, 14, 1416-1431.

Zhang, Y. Q., Chiew, F. H. S., Zhang, L., Leuning, R., \& Cleugh, H. A. (2008). Estimating catchment evaporation and runoff using MODIS leaf area index and the Penman-Monteith equation. Water Resources Research, 44, W10420.

Zhang, K., Kimball, J. S., Nemani, R. R., \& Running, S. W. (2010a). A continuous satellite-derived global record of land surface evapotranspiration from 1983 to 2006. Water Resources Research, 46, W09522.

Zhang, Y., Leuning, R., Chiew, F. H. S., Wang, E., Zhang, L., Liu, C., et al. (2011). Decadal trends in evaporation from global energy and water balances. Journal of Hydrometeorology, 13, 379-391.

Zhang, Y., Leuning, R., Hutley, L. B., Beringer, J., McHugh, I., \& Walker, J. P. (2010b). Using long-term water balances to parameterize surface conductances and calculate evaporation at $0.05^{\circ}$ spatial resolution. Water Resources Research, 46, W05512.

Zhao, M., Heinsch, F. A., Nemani, R. R., \& Running, S. W. (2005). Improvements of the MODIS terrestrial gross and net primary production global data set. Remote Sensing of Environment, 95, 164-176. 